\title{
THE NECESSITY AND POSSIBILITY OF A BINDING APPROACH TO INTERNATIONAL CORPORATE HUMAN RIGHTS RESPONSIBILITIES
}

\author{
Nicolás Carrillo- \\ Santarelli
}

\begin{abstract}
All victims of non-state violations, including corporate ones are entitled to a full protection. However, under State-centric and voluntary social responsibility paradigms, violations of businesses may remain in impunity and victims abandoned. This would be contrary to the foundation and main principles of international human rights law, namely human dignity, equality, and universality. In light of this, the article explores why international law permits to create direct corporate human rights obligations, and what strategies to protect and promote human rights from potential corporate abuses can be used.
\end{abstract}

Keywords: Non-state entities; international obligations; protection of human dignity; individual-centered analysis of international law; business and human rights.

\section{INTRODUCTION}

While they may have an impact on attitudes and be relevant, exclusively voluntary approaches to corporate respect of human rights, as corporate social responsibility principles, have shortcomings as the fact that they can be ignored without direct legal consequences and that exclusive reliance on them prevents the reparations of some victims whose human rights have been violated in events in which corporations participate. The fact that individuals are the protagonists of the human rights framework calls for examining how to better protect victims of all abuses, including corporate ones.

\footnotetext{
1 Profesor de Derecho Internacional de la Universidad Autónoma de Madrid. E-mail: nicolas.carrillos@gmail.com 
Businesses are sometimes factual agents of human rights abuses, and often have influence, power and capacities that enable them to challenge, diminish the effectiveness of or or circumvent State controls. ${ }^{2}$ Furthermore, due to delegation or privatization they sometimes have functions and powers with a direct impact on the enjoyment of human rights, as happens for instance with the provision of water; ${ }^{3}$ and can operate transnationally or taking advantage of the separate personality of entities in a corporate group and take advantage of gaps in domestic legal systems, sometimes eluding control. ${ }^{4}$

Those and other factors may lead to the lac of effective or full protection of some victims, given the shortcomings of strategies that only examine the responsibility of States, to be discussed later on, and violations may remain in impunity. Therefore, international legal processes (of regulation or supervision, among others) of a binding nature in relation to corporate conduct may be crucial to make up for the limits of voluntary and State-centered approaches.

Given the importance of holding entities that act contrary to important international legal interests and rights accountable, ${ }^{5}$ corporate offenders must be

\footnotetext{
${ }^{2}$ See Gatto, Alexandra, "Corporate Social Responsibility in the External Relations of the EU", in Yearbook of European Law, 24, 2005, at 423; del Arenal, Celestino, "La nueva sociedad mundial y las nuevas realidades internacionales: un reto para la teoría y para la política", in Cursos de Derecho Internacional y Relaciones Internacionales de Vitoria-Gasteiz 2001, Bilbao, 2002, at 27-28, 34, 52-53, 64-66; Galindo Vélez, Francisco, "Consideraciones sobre la determinación de la condición de refugiado”, in Sandra Namihas (Ed.), Derecho Internacional de los Refugiados, Pontificia Universidad Católica del Perú - Instituto de Estudios Internacionales, Fondo Editorial, 2001, pp. 125-126.

${ }^{3}$ See Reinisch, August, "The Changing International Legal Framework for Dealing with Non-State Actors", in Philip Alston (ed.), Non-State Actors and Human Rights, Oxford University Press, 2005, pp. 75-76, 8o-82; Human Rights Council, Resolution 15/9 adopted by the Council, Human rights and access to safe drinking water and sanitation, A/HRC/RES/15/9, 6 October 2010, paras. 7 and 9; Carolin F. Hillemanns, "UN Norms on the Responsibilities of Transnational Corporations and Other Business Enterprises with regard to Human Rights", German Law Journal, vol. 04, 2003, pp. 1067, $1073,1076$.

${ }^{4}$ See Badia Martí, Anna, "Cooperación internacional en la lucha contra la delincuencia organizada transnacional”, in Victoria Abellán Honrubia and Jordi Bonet Pérez (Dirs.), La incidencia de la mundialización en la formación y aplicación del Derecho Internacional Público, Los actores no estatales: ponencias y estudios, Bosch Editor, 2008, at 319; Annan, Kofi A., "Foreword", United Nations Convention against Transnational Organized Crime and the Protocols Thereto, United Nations Office on Drugs and Crime, 2004, pp. iii-iv. Available on: http://www.unodc.org/documents/treaties/UNTOC/Publications/TOC\%2oConvention/TOCebooke.pdf

${ }^{5}$ See José Manuel Cortés, Las Organizaciones Internacionales: Codificación y Desarrollo Progresivo de su Responsabilidad Internacional, Instituto Andaluz de Administración Pública, 2008, pp. 56-58. 
addressees of legal obligations and responsibilities: $:^{6}$ therefore, it must be examined if corporations capable of violating international human rights law (at the very least the fundamental ones) already have international duties, case in which breaches will automatically engage their legal responsibility, ${ }^{7}$ and if they do not further regulation will be required de lege ferenda. After all, the legitimacy of the system may be eroded if it is denied that corporate entities can violate human rights and must have obligations to refrain from doing so, ${ }^{8}$ as demanded by a victim- and individual-centered approach and current understandings that the content of human rights is central, rather than the identity of just some possible duty-holders (e.g. States). ${ }^{9}$ In turn, the importance of the presence of international strategies of protection, subject to complementarity and subsidiarity considerations, ${ }^{10}$ is due to the limits of domestic controls.

\section{WHY THE FOUNDATIONS OF HUMAN RIGHTS CALL FOR INTERNATIONAL CORPORATE OBLIGATIONS}

The legal foundation and core principles of international human rights law require that corporate duties exist for protection to have prospects of effectiveness and being full: some of those obligations exist already, and others must be created de lege ferenda.

\footnotetext{
${ }^{6}$ See Nijman, Janne E., "Non-state actors and the international rule of law: Revisiting the 'realist theory' of international legal personality", Amsterdam Center for International Law Research Paper Series, Non-State Actors in International Law, Politics and Governance Series, 2010, at 3, 4, 7-19, 3940.

${ }^{7}$ See International Law Commission, Draft Articles on the Responsibility of States for Internationally Wrongful Acts, with commentaries, 2001, at 31, paras. 1-3 of the General commentary.

${ }^{8}$ See Jochnick, Chris, "Confronting the Impunity of Non-State Actors: New Fields for the Promotion of Human Rights", Human Rights Quarterly, Vol. 21, 1999, pp. 58, 60-61; Clapham, Andrew, Human Rights Obligations of Non-State Actors, Oxford University Press, 2006, pp. 44, 50, 534, 546.

9 See Pariotti, Elena, "Non-State Actors, International Law, and Human Rights", in Sanford R. Silverburg (ed.), International Law: Contemporary Issues and Future Developments, Westview Press, 2011, at 96; Annyssa Bellal and Stuart Casey-Maslen, "Enhancing Compliance with International Law by Armed Non-State Actors", Goettingen Journal of International Law (GoJIL), Vol. 3, 2011, pp. 186187.

${ }^{10}$ On the relevance of those criteria, see Carozza, Paolo G., "Subsidiarity as a Structural Principle of International Human Rights Law", American Journal of International Law, Vol. 97, 2003, pp. 78-79; Darryl Robinson, "The Mysterious Mysteriousness of Complementarity", Criminal Law Forum, Vol. 21, No. 1, 2010.
} 
To begin with, the protection of human dignity, which is the foundation of international human rights law, ${ }^{11}$ is non-conditional or unconditional, ${ }^{12}$ which means that it cannot be made dependent on any factors different from the human identity of those who must be protected. This implies that the protection of human dignity and the rights (that must be) founded upon it $^{13}$ cannot be made dependent on the presence of an offender with a State identity, which explains why some NGOs and actors concerned with human rights condemn non-state violations. ${ }^{14}$ Furthermore, all victims suffer, and thus the prevention of and appropriate response to all violations, for instance State or corporate, are important. ${ }^{15}$

Furthermore, all outrages against the inherent worth and against legitimate free choices of individuals are contrary to the protection of human dignity, ${ }^{16}$ and corporations can engage in such misdeeds, reason why individuals must be protected from them. To do so, in the first place the existence of the capacity of corporations to violate human rights must be recognized, because denying such capacity ultimately amounts to denying fundamental entitlements of victims.

\footnotetext{
${ }^{11}$ See Villán Durán, Carlos, Curso de Derecho Internacional de los Derechos Humanos, Editorial Trotta, 2006, pp. 63-92; Daniel O’Donnell, Derecho Internacional de los Derechos Humanos, Oficina en Colombia del Alto Comisionado de las Naciones Unidas para los Derechos Humanos, 2004, at 66; Keitner, Chimène I., "Rights Beyond Borders", The Yale Journal of International Law, vol. 36, 2011, at 113; Roberto Andorno, "Human dignity and human rights as a common ground for a global bioethics", Journal of Medicine and Philosophy, 2009, at 4 (version available at: http://www.unesco.org.uy/ci/fileadmin/shs/redbioetica/dignidad_Andorno.pdf, last checked: 31/o1/2014); Oscar Schachter, "Human Dignity as a Normative Concept", American Journal of International Law, Vol. 77, 1983, at 853.

${ }^{12}$ See Sensen, Oliver, "Human Dignity in Historical Perspective: The Contemporary and Traditional Paradigms", European Journal of Political Theory, Vol. 10, 2011; Donnelly, Jack, "Human Rights and Human Dignity: An Analytic Critique of Non-Western Conceptions of Human Rights", The American Political Science Review, Vol. 76, 1982, at 310; Andorno, Roberto, op. cit., at 6.

${ }^{13}$ See Andorno, Roberto, op. cit., at 10; Resolution 41/120 of the General Assembly of the United Nations; Helsinki Final Act of 1 August 1975 of the Conference on Security and Co-Operation in Europe; Preamble to the Vienna Declaration and Programme of Action of the World Conference on Human Rights of 1993; Preambles to the International Covenants on Economic, Social and Cultural Rights and on Civil and Political Rights.

${ }^{14}$ See Clapham, Andrew, Human Rights Obligations of Non-State Actors, op. cit., pp. 43-44, 49-51.

${ }^{15}$ See Inter-American Court of Human Rights, Case of Velásquez-Rodríguez v. Honduras, Judgment of Merits, 29 July 1988, paras. 166, 172-174, 176, 177.

${ }^{16}$ See Clapham, Andrew, Human Rights Obligations of Non-State Actors, op. cit., pp. 545-546. Oscar Schachter, op. cit., pp. 851-852; Articles 10 of the International Covenant on Civil and Political Rights 28.2, 37.c and 40 of the Convention on the Rights of the Child, 5.2, 6.2 and 11.1 of the American Convention on Human Rights, 5 of the African Charter on Human and Peoples' Rights, or 3 of the Protocol to the African Charter on Human and Peoples' Rights on the Rights of Women in Africa, among others.
} 
On the other hand, the peremptory principle of equality and non-discrimination, with which all international norms must be consistent, ${ }^{17}$ also demands protecting victims from all abuses, including corporate ones, in an effective way, and corporate social responsibility strategies may fail to do so and thus must be complemented by binding strategies. Otherwise, victims of corporations will be discriminated against, especially if the domestic law of the host countries, that is to say those in which corporations operate, is unable to protect from corporate abuses or to ensure the reparation of victims: a substantive prohibition of corporate misdeeds will authorize third States and international organs to condemn them and eventually to take action, apart from the symbolic impact it may have on corporate conduct and attitudes.

Furthermore, the principle of equality binds non-state actors themselves, including businesses, and prohibits them from discriminating against human beings; ${ }^{18}$ and it also guides how human rights provisions are to be interpreted and applied. ${ }^{19}$

It must be noted that unintended and indirect discrimination are prohibited as well. ${ }^{20}$ Consequently, since individuals in the same fundamental substantive situation must be protected with an equivalent degree of effectiveness, ${ }^{21}$ it must be ensured that in practice victims of corporate violations have an effective access to meaningful remedies -as those to which victims of violations attributable to other actors-, taking into account that all victims deserve adequate legal protection regardless of who attacks them. ${ }^{22}$

\footnotetext{
${ }^{17}$ Ibid., paras. 100-101.

${ }^{18}$ Ibid., paras. 100, 140, 146; article 28 of the African (Banjul) Charter on Human and Peoples' Rights.

${ }^{19}$ See Inter-American Court of Human Rights, Advisory Opinion OC-18/03, op. cit., paras. 83, 94, 96; Human Rights Committee, General Comment No. 18, Non-discrimination, 10 November 1989, paras. $1-3,12$.

${ }^{20}$ See Advisory Opinion OC-18/03, op. cit., par. 103; Committee on Economic, Social and Cultural Rights, General Comment No. 16, The equal right of men and women to the enjoyment of all economic, social and cultural rights (art. 3 of the International Covenant on Economic, Social and Cultural Rights), E/C.12/2005/4, 11 August 2005, para. 13; European Court of Human Rights, Grand Chamber, Case of Oršuš and other v. Croatia, Judgment, op. cit., para. 85; Joint Party Dissenting Opinion of Judges Jungwiert, Vajić, Kovler, Gyulumyan, Jaeger, Myjer, Berro-Lefèvre and Vučinić to: European Court of Human Rights, Grand Chamber, Case of Oršuš and other v. Croatia, Judgment, 16 March 2010, para. 2.

${ }^{21}$ Inter-American Court of Human Rights, Advisory Opinion OC-18/o3, op. cit., paras. 89-93.

${ }^{22}$ See Almqvist, Jessica, "Facing the Victims in the Global Fight against Terrorism", FRIDE Working Paper 18, 2006, pp. 10-17, 20.
} 
Another pertinent basic feature of the international protection of human rights law is their universality. ${ }^{23}$ While it is frequently understood as requiring their protection in every State regardless of contrary attitudes, ${ }^{24}$ the term itself suggests that it demands a complete protection of human rights: not only geographically, but also in the ratione personae dimension, that is from every participant in violations, including businesses. ${ }^{25}$

Protection from corporate abuses, on the other hand, must not be limited to just some human rights, taking into account that businesses -as all State and non-state entities- can act against every human right, for instance by intimidating those who want to exercise them. ${ }^{26}$

For the reasons discussed in this section, it can be argued that the foundation and basic features of international human rights law demand full and effective protection from all abuses, including corporate ones. Hence, if State duties or corporate social responsibility strategies are insufficient to ensure it changes must be introduced.

\section{HOW INTERNATIONAL LAW CAN DEAL WITH CORPORATE ABUSES}

For protection to be complete, it must be given from all forms of corporate participation in violations, be it complicity, perpetration or else, being it important to consider that non-state actors can be complicit in violations of States or other entities. ${ }^{27}$

\footnotetext{
${ }^{23}$ See Vienna Declaration and Programme of Action, adopted on 25 June 1993, paras. I.1, I.5, I.6 and I.37.

${ }^{24}$ Ibid.

${ }^{25}$ Similarly, see Pariotti, Elena, op. cit., at 96.

${ }^{26}$ See Protect, Respect and Remedy: a Framework for Business and Human Rights, Report of the Special Representative of the Secretary-General on the issue of human rights and transnational corporations and other business enterprises, John Ruggie, A/HRC/8/5, 7 April 2008, paras. 6, 51-52; Guiding Principles on Business and Human Rights: Implementing the United Nations "Protect, Respect and Remedy" Framework, Report of the Special Representative of the Secretary General on the issue of human rights and transnational corporations and other business enterprises, John Ruggie, A/HRC/17/31, 21 March 2011, commentary to Principle 12, at 13; Inter-American Commission on Human Rights, "Third Report on the Human Rights Situation in Colombia", OEA/Ser.L/V/II.102, Doc. 9 rev. 1, 26 February 1999, paras. 3, 33-38 of Chapter IX, "Freedom of Association and Political Rights"; articles 25 of the International Covenant on Civil and Political Rights, 23 of the American Convention on Human Rights, and 3 of the Protocol to the European Convention for the Protection of Human Rights and Fundamental Freedoms.

${ }^{27}$ See International Court of Justice, Case concerning the Application of the Convention on the Prevention and Punishment of the Crime of Genocide (Bosnia and Herzegovina v. Serbia and Montenegro), Judgment, 26 February 2007, paras. 419-420; Inter-American Court of Human Rights, Advisory Opinion OC-14/94, International Responsibility for the Promulgation and Enforcement of Laws in Violation of the Convention, 9 December 1994, para. 56; Reinisch, August, op. cit., pp. 65-67; Cassese, Antonio, "When May Senior State Officials Be Tried for International Crimes? Some vol.08, nº . 01, Rio de Janeiro, 2015. pp. 420-457 425
} 
As to the possible forms of protection, international law can address non-state abuses indirectly and directly, i.e. regulating the duties of authorities to prevent and respond to corporate abuses and directly regulating or supervising the conduct of businesses, for instance imposing duties to respect human rights on them. ${ }^{28}$

In addition to this, the ways in which international law can deal with corporate conduct can be further classified in three ways:

1. Firstly, when examining whether certain corporate conduct is or can be detrimental to the enjoyment of human rights in order to assess whether authorities (States or not, as for instance the European Union) have properly prevented or responded to those threats in an effective and appropriate manner (regulating or sanctioning the conduct, among others). One example of this possibility is found in the Elmi v. Australia case. ${ }^{29}$ It must be noted that there may be cases in which the respective authority does not breach the law due to its having behaved diligently but nonetheless there is a corporate violation that must be addressed for the victims to be protected. In this regard, it must be recalled that the international responsibility of authorities in connection with

Comments on the Congo v. Belgium Case", European Journal of International Law (EJIL), Vol. 13, 2002, at 864; Inter-American Court of Human Rights, Case of Castillo-Petruzzi et al. v. Peru, Judgment, 30 May 1999, para. 90; Lauterpacht, Hersch, Steven \& Sons Limited, 1950, at 42; Norms on the responsibilities of transnational corporations and other business enterprises with regard to human rights, Sub-Commission on the Promotion and Protection of Human Rights, Fifty-fifth session, E/CN.4/Sub.2/2003/12/Rev.2, 26 August 2003, para. 1; Clapham, Andrew and Jerbi, Scott, "Categories of Corporate Complicity in Human Rights Abuses", Hastings International and Comparative Law Journal, Vol. 24, 2001; articles 14, 17, 18, 42 and 58 through 62 of the Draft Articles on the Responsibility of international organizations drafted by the International Law Commission and adopted by it in 2011, A/66/10, 2011.

${ }^{28}$ See Knox, John H., "Horizontal Human Rights Law", American Journal of International Law, Vol. 102, No. 1, 2008, pp. 1-2, 20-31.

${ }^{29}$ See European Court of Human Rights, Case of N. v. Sweden, Application no. 23505/o9, Judgment, 20 July 2010; European Court of Human Rights, Case of Rantsev v. Cyprus and Russia, Judgment, 7 January 2010, para. 319; European Court of Human Rights, Case of Opuz v. Turkey, Judgment, 9 June 2009, para. 159; European Court of Human Rights, Fourth Section, Case of Hajduová v. Slovakia, Judgment, 30 November 2010, para. 45-46, 50; Inter-American Court of Human Rights, Case of Ximenes-Lopez v. Brazil, Judgment of 4 July 2006, paras. 86, 89-90, 141; Inter-American Commission on Human Rights, Case of Jessica Lenahan (Gonzalez) et al. v. United States, Case 12.626, Merits Report No. 80/11, 21 July 2011, paras. 119, 122, 128; Inter-American Court of Human Rights, Case of González et al. ("Cotton Field") v. Mexico, Judgment, 16 November 2009, paras. 236, 245, 247, 254, 280; Inter-American Court of Human Rights, Advisory Opinion OC-18/o3, op. cit., paras. 140-153, 156157, 160; Committee on Economic, Social and Cultural Rights, Committee on Economic, Social and Cultural Rights, General Comment 12, The right to adequate food (art. 11), E/C.12/1999/5, 12 May 1999, para. 15 . 
non-state threates often emerges only if there has been a lack of due diligence (the standard of that diligence is greater when authorities generate risks of nonstate violations), and so is not engaged with every non-state violation of human rights. ${ }^{30}$ In such events, if corporations take advantage of the different personality of members of a business group, or of different norms of host and home states, among others, and effectively challenge, elude or circumvent internal controls, it cannot be said that State obligations are sufficient to protect victims and ensure their reparations, since the State will have no responsibility. Given the uncertainty of voluntary approaches and how they can be set aside, in those events it is important to give direct entitlements to individuals to claim against the corporate offenders.

2. For the aforementioned reasons reasons, corporate participation in violations of human rights is legally relevant insofar as it affects legal goods and individuals, and must be branded as internationally unlawful: in some events this is already recognized in lex lata (e.g. regarding violation of customary peremptory norms or international humanitarian law or criminal provisions). Regulating the prohibitions and duties of corporations permits their conduct to be directly examined and criticized in international human rights legal terms.

Such labelling has additional important consequences: it empowers and authorizes different participants ${ }^{31}$ in the international society, as authorities, to uphold the norms against corporate abuses, ${ }^{32}$ and legitimizes the initiatives of actors that criticize corporate misdeeds, empowering their arguments since it endows them with the power of criticizing abuses of human rights and international law, which are stigmatized.

\footnotetext{
$3^{30}$ See Inter-American Court of Human Rights, Case of González et al. ("Cotton Field") v. Mexico, Judgment, op. cit., paras. 248, 252-256, 258, 280, 283, 287, 293; European Court of Human Rights, Case of Mastromatteo v. Italy, Judgment, 24 October 2002, para. 68.

${ }^{31}$ On the notion of participants in the "international legal system", i.e. regarding international legal procedures and dimensions, see Rosalyn Higgins, Problems and Process: International Law and How We Use It, Oxford University Press, 2004, pp. 49-50.

${ }^{32}$ On the community legal dimensions of the international society (not limited to States) see: Villalpando, Santiago, "The Legal Dimension of the International Community: How Community Interests are Protected in International Law", European Journal of International Law, Vol. 21, 2010, pp. 390-394, 400-401, 410; Cassese, Antonio, "Remarks on Scelle's Theory of "Role Splitting" (dédoublement fonctionnel) in International Law", European Journal of International Law, Vol. 1, 1990, pp. 226-231.
} 
On the other hand, indicating that corporate participation in violations is unlawful in substantive terms is important given the expressive function of law, ${ }^{33}$ which signals to everyone about the unacceptable character of that participation and can thus lead to changes in the attitudes of corporations and social actors, ${ }^{34}$ for instance due to the desire to not appear as disregarding accepted legal tenets and human rights responsibilities with a binding foundation, since accusations in that regard can harm the image of corporations and potentially expose them to sanctions. ${ }^{35}$ Moreover, regarding non-state violations as internationally unlawful can trigger processes of socialization to discourage violations; and makes it possible, even if host States fail to prohibit or tackle non-state violations due to their weakness, for other authorities (State or not) to address them because of their being unlawful under international law, making them thus unlawful everywhere, that is to say, it allows the use of mechanisms based on allegations of breaches of human rights or international law. ${ }^{36}$ Those reasons, and processes that exert pressure on compliance, make advisable to adopt instruments on corporate responsibilities under international law, which have another advantage: they can dispel doubts and settle debates on whether corporations have international human rights obligations, which is an issue debated by some (both corporations and States) that attach priority to profit over human concerns.

In my opinion, corporate conduct must be considered as unlawful under international law at the very least when it implies involvement in the following types of

\footnotetext{
33 On the expressive function and effects of law, see: Goodman, Ryan and Jinks, Derek, "Incomplete Internalization and Compliance with Human Rights Law”, European Journal of International Law, Vol. 19 no. 4, 2008, at 735; García Villegas, Mauricio, "De qué manera se puede decir que la Constitución es importante”, in Álvarez Jaramillo et al., Doce ensayos sobre la nueva Constitución, Diké, 1991, at 40.

${ }^{34}$ See Fred Halliday, "The Romance of Non-state Actors”, in Daphné Josselin and William Wallace (eds.), Non-state Actors in World Politics, Palgrave (ed.), 2001, at 35.

${ }^{35}$ See Protect, Respect and Remedy: a Framework for Business and Human Rights, op. cit., pp. 27-32.

${ }^{6}$ On socialization and other processes promoting compliance and respect, see Capie, David, "Influencing Armed Groups: Are there Lessons to Be Drawn from Socialization Literature?", in: Geneva Call, Exploring Criteria \& Conditions for Engaging Armed Non-State Actors to Respect Humanitarian Law \& Human Rights Law, Conference Report-Geneva, 4-5 June 2007, 2008; Koh, Harold, "Why Do Nations Obey International Law?", The Yale Law Journal, vol. 106, 1997, at 260o2601. Regarding the possible failure of States, as described in the main body of the text, and some reasons that can lead to it, see International Law Association, Non-State Actors Committee, Washington Conference (2014), Draft $3^{\text {rd }}$ report prepared by the co-rapporteurs, Cedric Ryngaert and Jean d'Aspremont, pp. 11-12; Gatto, Alexandra, op. cit., at 423; Galindo Vélez, Francisco, op. cit., pp. $125-126$.
} 
violations: violations of jus cogens and of international criminal law; massive or systematic violations; and violations with especially appalling or worrisome features, given the urgent need to protect victims. The first two categories are already prohibited under international customary law. John Ruggie also takes into account the seriousness of violations, arguing that they must be dealt with in normative terms to tackle "governance gaps." That being said, I posit that every violation in which a corporation participates must generate its responsibility due to the effects described above. This does not mean that international bodies must check every one of them -they can still pay special attention to the serious ones-, but their being considered to be prohibited permits and bolsters different initiatives.

The direct prohibition of corporate or other non-state participation in abuses under international law implies that the conduct of businesses can be examined in light of it. This examination can even be conducted by international bodies or agents. Such supervision can be conditioned to the fulfilment of certain requirements. For example, the conduct of the UNMIK was analyzed by the Human Rights Committee because it administered a territory, given the need to ensure that the human rights of the population of that territory are protected regardless of who administers it. ${ }^{37}$

Conversely, the international supervision of corporate conduct can be a direct and unconditioned, as would have happened if the proposal to make corporations subject to the jurisdiction of the International Criminal Court had been successful -it must be stressed that international criminal law can outlaw violations of human rights and so protect them-..$^{8}$

It is important to turn to the analysis of the argument that, acknowledging the limits of State obligations and responsibility, corporate social responsibility and other voluntary approaches and principles, as those contained in codes of conduct, could be sufficient to ensure the respect of human rights by corporations.

It is true that voluntary initiatives can contribute to shaping corporate culture and attitudes or even be the inspiration of future legal reforms, taking into account that human rights and the strategies to promote them have not only legal and judicial but

\footnotetext{
${ }^{37}$ See Human Rights Committee, Concluding Observations on Kosovo (Serbia), CCPR/C/UNK/CO/1, 14 August 2006, paras. 4, 8-22.

${ }^{38}$ See Lauterpacht, Hersch, International Law and Human Rights, op. cit., pp. 35-37. vol.08, $n^{\circ}$. 01, Rio de Janeiro, 2015. pp. 420-457 
also ethical, social and other dimensions, ${ }^{39}$ reason why initiatives to refer to them, for instance in agreements or internal statements (e.g. as communications or agreements in which the European Union has participated, or agreements entered into by Canada ${ }^{40}$ must be commended. Nevertheless, it cannot be ignored that voluntary initiatives have shortcomings, some of which are specially troublesome or relevant.

Among those limitations, the following can be mentioned: their very voluntary nature implies that they can be set aside by their addressees without any direct legal repercussion (they may eventually produce indirect legal effects); ${ }^{41}$ affected individuals often lack access to remedies and mechanisms with prospects of effectively protecting them and leading to the declaration of the breach of corporate duties; ${ }^{42}$ or they can being invoked merely to improve the image of a corporation with no real commitment to the respect human rights. ${ }^{43}$ For those reasons, voluntary initiatives must be complemented by legally binding legal processes, such as regulation and supervision based on international law. The conditions and possibilities of that regulation which will be explored in the next section.

\section{CONDITIONS TO CREATE INTERNATIONAL HUMAN RIGHTS OBLIGATIONS OF BUSINESSES}

Different requirements must be satisfied to create corporate human rights obligations under international law. Logically, the first step is for them to be created by the sources of international law -either primary or secondary ones, as through resolutions of the Security Council, which can impose duties on non-state actors-. ${ }^{44}$

\footnotetext{
${ }^{39}$ See Sen, Amartya, "Elements of a Theory of Human Rights", Philosophy \& Public Affairs, Vol. 32 , 2004, pp. 325-328, 342-345, 349, 355-356; Knox, John H., op. cit., pp. 43-44.

${ }^{40}$ Gatto, Alexandra, op. cit., pp. 432-454; Inter-American Commission on Human Rights, Hearing on the Impact of Canadian Mining Activities on Human Rights In Latin America, held on the 28th of October, 2014, available here: https://www.youtube.com/watch?v=OWYue8FP9ZY

${ }^{41}$ See International Law Association, Non-State Actors Committee, Report: Preliminary issues for the ILA Conference in Rio de Janeiro, 2008, at 3.

${ }^{42}$ See Reinisch, August, op. cit., pp. 52-53; Gatto, Alexandra, op. cit., at 431; Corporate Responsibility, the corporate responsibility coalition, "Protecting rights, repairing harm: How state-based nonjudicial mechanisms can help fill gaps in existing frameworks for the protection of human rights of people affected by corporate activities", briefing paper for the UN Secretary General's Special Representative on Business and Human Rights, 2010, at 4.

${ }^{43}$ See Ibid.

${ }^{44}$ 'Secondary law' is a term borrowed from European Union Law. See "Sources of European Union law",

available at: vol.08, nº. 01, Rio de Janeiro, 2015. pp. 420-457 430
} 
Regarding treaties, the negotiators could require the consent of corporate addressees for them to be bound (see, in comparison regarding other non-state actors, article 96.3 of Protocol I to the Geneva Conventions of 1949), but that is not necessary and corporate duties of corporations can be enacted without requiring their consent.

Additionally, fundamental rights ${ }^{45}$ and guarantees have to be respected for the regulation of corporate duties to respect the rule of law. Among them, the principle of legality stands out (but is not the only one), requiring that knowledge of the content of duties is foreseeable and accessible, happens with the regulation of all non-state duties (one case that discusses this in relation to individuals is the Kononov v. Latvia case). ${ }^{46}$ Another substantive requirement is that the corporate obligations respect jus cogens.

Finally, it can be said that the obligations in question can be had by the respective corporations logically, factually and normatively, taking into account that, as other entities, they must have the capacity to have legal burdens in order for them to possess them. ${ }^{47}$

If the conditions to create a corporate obligation are satisfied, those bound by it will become subjects of international law due to their being its addressees.$^{48}$ After all,

http://europa.eu/legislation_summaries/institutional_affairs/decisionmaking_process/li4534_en.htm (last checked: 04/02/2014). Moreover, see: International Court of Justice, Accordance with International Law of the Unilateral Declaration of Independence in respect of Kosovo, Advisory Opinion, Advisory Opinion, 22 July 2010, paras. 115-116; Marko Milanovic, "A Few Thoughts on Resolution 2118 (2013)”, EJIL: Talk!, 1 October 2013; Security Council Resolution 2118 (2013)..

${ }^{45}$ While human rights are those of individuals based on their inherent worth, other entities may have rights of a fundamental importance, the content of which sometimes may resemble that of certain human rights. The European Convention for the Protection of Human Rights and Fundamental Freedoms permits applications of non-state entities that consider themselves as victims of violations contrary to that treaty, and the choice of words of the instrument's title could be construed as implying that non-individual entities may have fundamental rights but certainly not the former, due to their not being human. Supporting the ideas on the features of human rights expressed in this paragraph, see Human Rights Committee, General Comment No. 31, The Nature of the General Legal Obligation Imposed on States Parties to the Covenant, CCPR/C/21/Rev.1/Add. 13, 26 May 2004, para. 9; Alvarez, José E., "Are Corporations "Subjects" of International Law?", Santa Clara Journal of International Law, Vol. 9, 2011, pp. 9-11, 17-19; Finnis, John, "The Priority of Persons", in Jeremy Horder (ed.), Oxford Essays in Jurisprudence, Fourth Series, Oxford University Press, 20oo, pp. 6-9.

${ }^{46}$ See European Court of Human Rights, Grand Chamber, Case of Kononov v. Latvia, Judgment, 17 May 2010, paras. 185-187, 205-213, 235-239.

${ }^{47}$ See Pentassuglia, Gaetano, "Review of: Meijknecht, Anna. Towards International Personality: The Position of Minorities and Indigenous Peoples in International Law", European Journal of International Law, Vol. 14, 2003, at 391; Meijknecht, Anna, Towards International Personality: The Position of Minorities and Indigenous Peoples in International Law, Intersentia, 2001, pp. 34-42, 44, 61.

${ }^{48}$ See Klabbers, Jan, International Law, Cambridge University Press, 2013, locations 2533-2540 (kindle edition); Portmann, Roland, Legal Personality in International Law, Cambridge University Press, 
international law can directly regulate non-state conduct without the mediation of internal legal systems. ${ }^{49}$

Another important aspect is that international law can regulate duties of nonstate actors -among which corporations are included- expressly or by implication, without expressly referring to those actors. ${ }^{50}$ Just international organizations have those capacities that are necessary for the achievement of their goals, ${ }^{51}$ the respect of human rights might be accompanied by implied obligations that are correlative the respect of those rights.

The previous arguments defend the idea that it is possible for corporations to have international human rights obligations. Furthermore, the creation of those obligations is not only possible but also consistent with the evolutionary character of human rights and international law, with the evolution in the understanding of the notion of legal personality, ${ }^{52}$ and also important to defend human dignity.

2010, pp. 271-283; Anna Meijknecht, op. cit., pp. 32-62; Pariotti, Elena, op. cit., at 102; Clapham, Andrew, Human Rights Obligations of Non-State Actors, op. cit., pp. 59-75; José Manuel Cortés Martín, op. cit., pp. 109-111.

${ }^{49}$ See European Court of Human Rights, Grand Chamber, Case of Kononov v. Latvia, op. cit., paras. 185-187, 205-213, 236-239; Principles of International Law recognized in the Charter of the Nürnberg Tribunal and in the Judgment of the Tribunal, with commentaries, Yearbook of the International Law Commission, vol. II, 1950, Principle I in conjunction with paragraph 99 therein, at 374; Meron, Theodor, The Humanization of International Law, Martinus Nijhoff, 2006, pp. 40-41.

${ }^{50}$ See European Court of Human Rights, Grand Chamber, Case of Kononov v. Latvia, op. cit., paras. 236-237; International Court of Justice, Reparation for Injuries Suffered in the Service of the United Nations, Advisory Opinion, 11 April 1949, pp. 12-13 (or 182-183, depending on the numeration of the document); "The Reality of Private Rights, Duties, and Participation in the International Legal Process", Michigan Journal of International Law, vol. 25, 2004, pp. 1242-1243.

${ }^{51}$ See Special Tribunal for Lebanon, Appeals Chamber, Case No. CH/AC/2010/o2, Decision on Appeal of Pre-Trial Judge's Order regarding Jurisdiction and Standing, 1o November 2010, paras. 44-49; InterAmerican Court of Human Rights, Case of the Constitutional Court v. Peru, Judgment (competence), 24 September 1999, paras. 31-33.

${ }^{2}$ Not only the content of international law, but also how it is interpreted and applied are largely subject to evolutionary developments, and its branch of international human rights law is fully so. See: Inter-American Court of Human Rights, Advisory Opinion OC-10/89, Interpretation of the American Declaration of the Rights and Duties of Man within the Framework of article 64 of the American Convention on Human Rights, 14 July 1989, paras. 37-38; Inter-American Court of Human Rights, Case of the "Street Children" (Villagrán-Morales et al.) v. Guatemala, Judgment, 19 November 1999, para. 193; Marko Milanovic, "The ICJ and Evolutionary Treaty Interpretation”, EJIL: Talk!, 14 July 2009, available at: http://www.ejiltalk.org/the-icj-and-evolutionary-treaty-interpretation/ (last checked: 04/02/2014); International Court of Justice, Case concerning the Gabčíkovo-Nagymaros Project (Hungary/Slovakia), Judgment, 25 September 1997, paras. 112, 140; Jordan J. Paust, "Nonstate Actor Participation in International Law and the Pretense of Exclusion", Virginia Journal of International Law, Vol. 51, Number 4, 2011, pp. 985-100o. 
After all, it is important that all entities are bound to respect human rights: individuals, because they ultimately commit violations ${ }^{53}$ and collective or group actors, as corporations, because their resources and dynamics often permit, facilitate or worsen violations, reason why they must have legal responsibility as well. ${ }^{54}$

I will now turn to explore international human rights obligations that corporations have in lex lata and the content of other obligations that they can have.

\section{THE CURRENT AND POSSIBLE CONTENT OF CORPORATE INTERNATIONAL HUMAN RIGHTS OBLIGATIONS}

In current positive international law there is an obligation of everyone that can act contrary to it to refrain from violating or contributing in the violation of jus cogens norms, some of which protect human rights. ${ }^{55}$ Corporations have the capacity to participate in their violations, and so have the duty to not do so..$^{56}$

The implied obligation to respect peremptory human rights exists because of the following factors:

1. The principle of effectiveness ${ }^{57}$ coupled with the absolute prevalence of jus cogens ${ }^{58}$ outlawing all contrary conduct and manifestations. Concerning this, in

\footnotetext{
${ }^{53}$ See Principles of International Law recognized in the Charter of the Nürnberg Tribunal and in the Judgment of the Tribunal, with commentaries, op. cit., para. 99, at 374.

${ }^{54}$ See Klabbers, Jan, op. cit., locations 4532-4557 (kindle edition).

${ }^{55}$ See Gómez Robledo, Antonio, El Ius Cogens Internacional: Estudio histórico-crítico, Universidad Nacional Autónoma de México, 2003, 166-172; Inter-American Court of Human Rights, Advisory Opinion OC-18/03, Juridical Condition and Rights of Undocumented Migrants, op. cit., 86, 88, 97-101; ICTY, Prosecutor v. Anto Furundzija, Judgement, 10 December 1998, paras. 153-157; European Court of Human Rights, Case of Al-Adsani v. The United Kingdom, Judgment, 21 November 2001, paras. 30, 6o-61; Joint Dissenting Opinion of Judges Rozakis and Caflisch Joined by Judges Wildhaber, Costa, Cabral Barreto and VajiĆ Furundzija to: European Court of Human Rights, Case of Al-Adsani v. The United Kingdom, Judgment, op. cit., paras. 1-4; Human Rights Committee, General Comment No. 29, States of Emergency (article 4), CCPR/C/21/Rev.1/Add.11, 31 August 2001, para. 11.

${ }^{56}$ Roland Portmann, op. cit., pp. 166-167.

57 Regarding this principle, see Joint Dissenting Opinion of President Owada, Judges Simma, Abraham and Donoghue and Judge ad hoc Gaja to the Preliminary Objections Judgment of the International Court of Justice of 1 April 2011 in the Case concerning Application of the International Convention on the Elimination of all Forms of Racial Discrimination (Georgia v. Russian Federation), para. 22; Inter-American Court of Human Rights, Case of Baena-Ricardo et al. v Panama, Competence Judgment, 28 November 2003, paras. 66-67; European Court of Human Rights, Case of Giuliani and Gaggio v. Italy, Application no. 23458/o2, Judgment, 24 March 2001, para. 177; Remiro Brotóns, Antonio et al., Derecho Internacional: Curso General, Tirant Lo Blanch, 2010, at 377.

${ }^{58}$ See articles 53 and 64 of the Vienna Convention on the law of treaties concluded in 1969 and 26 and 50.1 of the articles on the Responsibility of States for Internationally Wrongful Acts drafted by vol.08, nº. 01, Rio de Janeiro, 2015. pp. 420-457 
the Furundzija case it was held that jus cogens prevails over and sanctions every contrary normative and factual manifestation, whoever its author is. ${ }^{59}$

2. The fact that jus cogens protects community goals and interests, which, as argued in the Reparation for Injuries case, can have an impact on international legal subjectivity and on the presence of legal capacities of non-state entities (e.g. international organizations). ${ }^{60}$ Law can regulate not only rights but also duties, and when duties are necessary for achieving international legal goods, especially the most important ones with a community value, ${ }^{61}$ they can implicitly bind all potential offenders. Furthermore, those duties can be possessed according to the notion of inherent capacities; and obligations flowing from peremptory law are erga omnes and so have a vertical dimension with effects in relation to non-state entities. ${ }^{62}$

3. The correlation between rights and obligations in international law ${ }^{63}$ lends support to the idea that, at the very least, peremptory human rights must be protected by the existence of correlative obligations, at least implicitly. This is supported by the opinion of the European Court of Human Rights that entities as individuals cannot ignore duties to not violate human rights even if, unlike States, they are not expressly their addressees. Authors as Jordan Paust have

the International Law Commission; Inter-American Commission on Human Rights, Report № 62/o2, Merits, Case 12.285, Michael Domingues v. United States, 22 October 2002, para. 49.

${ }^{59}$ See International Tribunal for the Prosecution of Persons Responsible for Serious Violations of International Humanitarian Law Committed in the Territory of the Former Yugoslavia since 1991, Prosecutor v. Anto Furundzija, Judgement, 10 December 1998, paras. 153-157.

${ }^{60}$ On the non-state character of international organizations, which are, after all, entities different from States in subjective terms, given their independence even if the latter are members of the former, being membership not limited to States, see arguments regarding their distinct features, as the ones mentioned herein, among others, in: International Law Commission, Draft Articles on the Responsibility of States for Internationally Wrongful Acts, with commentaries, op. cit., at 32, para. 4 of the General comentary; article 2.a of the Draft Articles on the Responsibility of international organizations of the International Law Commission, A/66/10, 2011; José Manuel Cortés, op. cit., pp. 111-114; Remiro Brotóns, Antonio et al., Derecho Internacional, Tirant Lo Blanch, 2007, at 233; Biró, Gáspar and Motoc, Antoanella-Iulia, Working paper on human rights and non-State actors, E/CN.4/Sub.2/2005/40, 11 July 2005, paras. 19, 25-26, 31, 35-39.

${ }^{61}$ See Villalpando, Santiago, op. cit., pp. 394, 401-407, 412, 418-419.

${ }^{62}$ See Concurring Opinion of Judge A. A. Cançado Trindade to: Inter-American Court of Human Rights, Advisory Opinion OC-18/o3, op. cit., paras. 77-78.

${ }^{63}$ It has been said that "some have considered the correlation of obligations and rights as a general as a general feature of international law". See International Law Commission, Draft Articles on the Responsibility of States for Internationally Wrongful Acts, with commentaries, 2001, para. 8 of the commentary to article 2 , at 35 . 
argued that some human rights guarantees may be protected by implicit corresponding non-state duties; ${ }^{64}$ and others have argued that norms and legal practice reveal that non-state entities are bound to respect human rights enshrined in peremptory law. ${ }^{65}$

In addition to the duty to respect jus cogens (which binds all entities due to their being potential offenders), there may be other international human rights obligations of corporations, the creation of which is advisable because they may participate in the violation of any human right and not every one of them is protected by peremptory norms. ${ }^{66}$ The special rights and needs of protection of vulnerable individuals and the unique features of corporations must be taken into account to better regulate corporate obligations. ${ }^{67}$

International human rights obligations of corporations can be: 1) implied or express; 2) formally found in different branches of international law (developments in one of them can inspire progress in the others); ${ }^{68} 3$ ) obligations of means or of result

\footnotetext{
${ }^{64}$ See Paust, Jordan J., "The Other Side of Right: Private Duties Under Human Rights Law”, Harvard Human Rights Journal, Vol. 5, 1992, pp. 53-54, 61-62.

${ }^{65}$ See Human Rights Council, Report of the independent international commission of inquiry on the Syrian Arab Republic, A/HRC/19/69, 22 February 2012, para. 106; Rodehäuser, Tilman, "Progressive Development of International Human Rights Law: The Reports of the Independent International Commission of Inquiry on the Syrian Arab Republic", EJIL: Talk!, 13 April 2013; Roland Portmann, op. cit., pp. 162-166; Bellal, Annyssa and Casey-Maslen, Stuart, op. cit., at 187; ICTY, Prosecutor v. Anto Furundzija, Judgement, 10 December 1998, paras. 155-157.

${ }^{66}$ See Human Rights Committee, General Comment No. 29, op. cit., para. 11; Antonio Gómez Robledo, El Ius Cogens Internacional: Estudio histórico-crítico, op. cit., pp. 166-172.

${ }^{67}$ See Dufresne, Robert, Review of: Liesbeth Zegveld, The Accountability of Armed Opposition Groups in International Law, European Journal of International Law, Vol. 15, 2004, at 227; Alvarez, José E., "Are Corporations "Subjects" of International Law?", Santa Clara Journal of International Law, Vol. 9, 2011, pp. 30, 33-35; Protect, Respect and Remedy: a Framework for Business and Human Rights, A/HRC/8/5, op. cit., para. 53; Cortés Martín, José Manuel, op. cit., pp. 211-223, 225-293; http://www.un.org/disabilities/convention/questions.shtml\#one (last checked: 05/02/2014); Gómez Isa, Felipe, "International Protection of Human Rights", in Felipe Gómez Isa and Koen de Feyter (eds.), International Protection of Human Rights: Achievements and Challenges, University of Deusto, 2006, pp. 24, 31; Meron, Theodor, "The Humanization of International Law", American Journal of International Law, Vol. 94, No. 2, 2000, at 239.

${ }^{68}$ After all, norms from different so-called branches actually protect shared legal goods, showing both that divisions between those branches are not hermetic and many of their norms belong to one same corpus juris, and thus that developments in one of them can be replicated or serve as inspiration in others. See Clapham, Andrew, Human Rights Obligations of Non-State Actors, op. cit., at 73; Brownlie, Ian, The Rule of Law in International Affairs: International Law at the Fiftieth Anniversary of the United Nations, Martinus Nijhoff Publishers, 1998, pp. 65-66.
} 
(e.g. a duty to make internal policies consistent with human rights); ${ }^{69} 4$ ) and negative (forbidding acting against human rights) or positive, commanding them to do something (they will likely be due diligence obligations).$^{70}$

Positive human rights obligations of corporations can certainly be created and can be compatible with a system of human rights, the foundation of which is human dignity. ${ }^{71}$ They can regulate demands in relation to events or roles in which requiring protection by corporations is sound, for instance when there are legitimate expectations of that protection, as can happen when a company: a) has a position of guarantor ${ }^{72}$-e.g. if it handles a prison or hospital-; b) has functions or powers with a direct impact on the enjoyment of human rights, as the provision of water ${ }^{73}$ c) creates a risk of violation, in which case it should prevent it from materializing; ${ }^{74} \mathrm{~d}$ ) is found to have violated human rights and has a positive duty to repair; or e) when the enjoyment of a human right

\footnotetext{
${ }^{69}$ See article 4 of the Convention on the Rights of Persons with Disabilities in conjunction with articles 42 through 45 thereof; and article 59.2 of the European Convention on Human Rights in light of the analysis of the customary obligation to adjust regulations to demands of international human rights law presented in: Inter-American Court of Human Rights, Advisory Opinion OC-18/03, op. cit., para. 77; paragraph 15 of the Norms on the responsibilities of transnational corporations and other business enterprises with regard to human rights.

${ }^{70}$ See Norms on the responsibilities of transnational corporations and other business enterprises with regard to human rights and the commentary on the Norms, E/CN.4/Sub.2/2003/12/Rev.2, paragraph b of the commentary to paragraph A.1.; Hillemanns, Carolin F., "UN Norms on the Responsibilities of Transnational Corporations and Other Business Enterprises with regard to Human Rights", German Law Journal, vol. 04, 2003, pp. 1072-1073; Protect, Respect and Remedy: a Framework for Business and Human Rights, A/HRC/8/5, op. cit., para. 72.

${ }^{71}$ See Clapham, Andrew, Human Rights Obligations of Non-State Actors, op. cit., pp. 546-547.

${ }^{72}$ On the use of the notion of the position of guarantor and the obligations of those in it as used in international human rights law, see Inter-American Commission on Human Rights, Press Release 114/10, "IACHR Deplores Acts of Violence in Prisons in Brazil"; Inter-American Commission on Human Rights, Press Release 19/12, "IACHR Deplores Deaths in Fire in Honduras Prison."

${ }^{73}$ See Human Rights Council, Resolution 15/9 adopted by the Council, Human rights and access to safe drinking water and sanitation, op. cit., para. 9; Human Rights Council, Report of the independent expert on the issue of human rights obligations related to access to safe drinking water and sanitation, Catarina de Albuquerque, A/HRC/15/31, 29 June 2010, para. 26.

${ }^{74}$ This criterion has been expressly invoked in order to examine State compliance with human rights obligations when States create a risk of a non-state violation, being it considered that duties to prevent and respond to them become stricter. See Inter-American Court of Human Rights, Case of the Pueblo Bello Massacre v. Colombia, Judgment, 31 January 2006, paras. 125-126. Supporting the consideration that non-state entities that generate a risk of a violation may be obliged to neutralize it, see Eser, Albin, "Individual Criminal Responsibility: Mental Elements-Mistake of Fact and Mistake of Law", Reprints from: Antonio Cassese et al. (eds.), The Rome Statute of the International Criminal Court: A Commentary, Oxford University Press, 2002, at 819; United States Court of Appeals for the Seventh Circuit, Boimah Flomo et al. v. Firestone Natural Rubber Co., LLC, Decision of 11 July 2011, pp., 20-22.
} 
directly and urgently depends on corporate action, as may happen in some emergency situations;.

The obligation to repair is quite important, because frequently full and effective reparations will not be possible unless corporations involved in abuses participate in them. This makes regulating primary obligations of them important, since they will be bound by secondary rules ${ }^{75}$ that, among others, command reparations, if they breach the former.

\section{CORPORATE RESPONSIBILITY AND THE FULL REPARATIONS OF VICTIMS}

The protection and wellbeing of human beings and victims must guide the analysis of every legal process, ${ }^{76}$ and this is no different when assessing issues of responsibility and reparations. ${ }^{77}$ Concerning them, it must be noted that apart from the fact that responsible actors must repair, ${ }^{78}$ victims are entitled to full reparations. ${ }^{79}$ Therefore, if victims cannot be fully repaired unless corporate participants in violations participate in reparations, it follows that those actors must have the duty to repair, a condition of which is their having primary obligations: social or non-legal

\footnotetext{
${ }^{75}$ See International Law Commission, Draft Articles on the Responsibility of States for Internationally Wrongful Acts, with commentaries, op. cit., paragraphs 1 and 3 of the General commentary, at 31; International Law Commission, Draft Articles on the Responsibility of international organizations, with commentaries, A/66/10, 2011, paragraph 3 of the General commentary, at 2, and article 31 and Chapter II of Part Three of these articles; Basic Principles and Guidelines on the Right to a Remedy and Reparation, paragraphs 15,17 and 18.

${ }^{76}$ All the processes of law described by McDougal, rightly not limited to lawmaking, in which policy choices can have an undeniable impact, must be humanized. On those processes, see McDougal, Myres S. and Lasswell, Harold D., "The Identification and Appraisal of Diverse Systems of Public Order", The American Journal of International Law, Vol. 53, 1959, at 9-10; McDougal, Myres S., "Some basic theoretical concepts about international law: a policy-oriented framework of inquiry", The Journal of Conflict Resolution, Vol. IV, 1960, at 341-342, 345-350. Moreover, see John Finnis, op. cit.

${ }_{77}$ See van Boven, Theo, "The United Nations Basic Principles and Guidelines on the Right to a Remedy and Reparation for Victims of Gross Violations of International Human Rights Law and Serious Violations of International Humanitarian Law", United Nations Audiovisual Library of International Law, at 3.

${ }^{78}$ See article 31 and Chapter II of Part Two of the articles on the Responsibility of States for Internationally Wrongful Acts drafted by the International Law Commission.

${ }^{79}$ See the Basic Principles and Guidelines on the Right to a Remedy and Reparation (the very title of which is quite telling), especially but not exclusively Principle 18 thereof; and Saavedra Alessandri, Pablo, "Las Reparaciones en el Sistema Interamericano de Derechos Humanos", pp. 4, 14-16, available at: http://www.usergioarboleda.edu.co/instituto_derechos_humanos/material/cv/reparaciones.pdf (last checked: 05/04/2014); van Boven, Theo, op. cit., pp. 2-3, 5.
} 
responsibilities are not sufficient, because they do not ensure that corporations have an obligation to repair and thus permit their refraining from doing so with no legal consequence. $^{80}$

Truly, sometimes reparations cannot be full unless the corporations that participated in a violation, even as accomplices, do not repair victims. This can be the result of limitations in compensations according to what participants in violations owe victims in relation to their own contribution to damage, reason why not obliging corporations involved may lead to the absence of full compensation. ${ }^{81}$ The absence of full reparations could also be related to the component of satisfaction: for instance, for apologies to be truly meaningful for victims and have a full psychological effect they must be given by all entities involved in a violation; or for the whole truth surrounding a violation to be revealed ${ }^{82}$ it may be necessary for a company that is the only one to know part of it to reveal it. ${ }^{83}$

The previous considerations are also relevant in relation to another consequence of responsibility: the guarantees of non-repetition. ${ }^{84}$ Common sense indicates that they must be given by all actors involved in a corporation, be them companies or not, to seek that they do not participate in similar violations in the future.

\footnotetext{
${ }^{80}$ On the nature and existence of extra-legal or non-legal responsibilities, including those of nonstate entities and States, and the international legal context, see Cheng, Bin, General Principles of Law as Applied by International Courts and Tribunals, Cambridge University Press, 2006, pp. 163-164; Wirtz, Raoul, "Moral responsibility in organizations", in: Ronald Jeurissen (ed.), Ethics \& Business, Royal Van Gorcum, 2007, pp. 24-26; Knox, John H., "The Human Rights Council Endorses "Guiding Principles" for Corporations", ASIL Insights, Vol. 15, Issue 21, 2011 (on societal expectations as different from binding norms); Remiro Brotóns, Antonio et al., Derecho Internacional, Tirant Lo Blanch, 2007, pp. 784-786.

${ }^{81}$ See Basic Principles and Guidelines on the Right to a Remedy and Reparation, para. 18; articles 31 and 34 through 38 of the Draft Articles on the Responsibility of international organizations drafted by the International Law Commission and adopted by it in 2011, and 31 and 34 through 38 of the articles on the Responsibility of States for Internationally Wrongful Acts drafted by the International Law Commission; Theo van Boven, op. cit., at 4.

${ }^{82}$ See van Boven, Theo, op. cit., at 5; Saavedra Alessandri, Pablo, op. cit., pp. 14-16, 19; Basic Principles and Guidelines on the Right to a Remedy and Reparation, paras. 22.b and 24.

${ }^{83}$ See paragraph 22.c of the Basic Principles and Guidelines on the Right to a Remedy and Reparation, and Saavedra Alessandri, Pablo, op. cit., pp. 15-17.

${ }^{84}$ See paragraph 18 and 23 of the Basic Principles and Guidelines on the Right to a Remedy and Reparation; Saavedra Alessandri, Pablo, op. cit., pp. 3 and 14; and articles 30 and 48.2.a of the articles on the Responsibility of States for Internationally Wrongful Acts drafted by the International Law Commission, and 30 and 49.4.a of the Draft Articles on the Responsibility of international organizations adopted by the International Law Commission in 2011.
} 
It may be asked if corporate responsibility could somehow undermine the international responsibility of States. Concerning this, State obligations will not disappear, as the Norms on the Responsibilities of Transnational Corporations and Other Business Enterprises with Regard to Human Rights recognized in their first paragraph. This is because in international law different entities can be responsible in connection with one same violation when each of them breaches its duties: those responsibilities will then coexist, as discussed in doctrine and case law. ${ }^{85}$

Each entity, including corporations -with their separate personality- responds for how it participated, e.g. as a perpetrator, accomplice or participant in joint illegal enterprises, among other possibilities. ${ }^{86}$ That is why the possible coexistence of responsibilities or companies and other actors is not contrary to the individualization of international responsibility, since they will respond for their own acts. ${ }^{87}$

The article will now turn to examine what initiatives and strategies can be employed to supervise corporate conduct in light of international human rights standards and encourage compliance with them.

\section{MECHANISMS AND STRATEGIES TO STRENGTHEN THE RESPECT OF HUMAN RIGHTS STANDARDS BY CORPORATIONS}

\footnotetext{
${ }^{85}$ See Inter-American Court of Human Rights, Advisory Opinion OC-14/94, op. cit., paras. 51-57; Cassese, Antonio, "When May Senior State Officials Be Tried for International Crimes? Some Comments on the Congo v. Belgium Case", op. cit., at 864, where it is mentioned that "there may coexist state responsibility and individual [...] liability"; International Court of Justice, Case concerning the Application of the Convention on the Prevention and Punishment of the Crime of Genocide, op. cit., paras. 419-420; Basic Principles and Guidelines on the Right to a Remedy and Reparation, principle 15 .

${ }^{86}$ See Eser, Albin, op. cit., pp. 789-793, 8o1; Manacorda, Stefano and Meloni, Chantal, "Indirect Perpetration versus Joint Criminal Enterprise: Concurring Approaches in the Practice of International Criminal Law?", Journal of International Criminal Justice, 2011, pp. 162-175; Keitner, Chimène I., "Conceptualizing Complicity in Alien Tort Cases", Hastings Law Journal, vol. 6o, 2008, pp. 88-89, 91, 93-96; articles 25 of the Rome Statute of the International Criminal Court and 7 of the Statute of the International Criminal Tribunal for the former Yugoslavia; Fielding, Alex, "Sainovic Appeal rejects 'specific direction', but was it necessary?", Beyond The Hague: Thoughts on international justice from The Hague and beyond, 24 January 2014, available at: http://beyondthehague.com/2014/o1/24/sainovic-appeal-rejects-specific-direction-but-was-itnecessary/ (last checked: 05/04/2014); Milanovic, Marko, "The Self-Fragmentation of the ICTY Appeals Chamber", EJIL: Talk!, 23 January 2014, available at: http://www.ejiltalk.org/the-selffragmentation-of-the-icty-appeals-chamber $\angle$ (last checked: 05/04/2014).

${ }^{87}$ See Cheng, Bin, op. cit., pp. 208, 210-212; Kelsen, Hans, Pure Theory of Law, University of California Press, 1978, pp. 326-328.
} 
For their rights to not be merely theoretical and illusory, individuals have a right to an effective legal protection of their fundamental entitlements -including protection from non-state abuses ${ }^{88}$ and reparations when corporations violate their rights.- Yet, since in international law substantive law is sometimes not accompanied by procedural guarantees $^{89}$ it is important to explore what lawful and proportionate mechanisms can be used to protect human beings from possible corporate abuses, bearing in mind that non-judicial strategies can play an important -but not exclusive- role..$^{90}$

Different initiatives and strategies can be used, each having its own strengths and weaknesses in a global landscape, reason why they must complement each other in a multi-level and multi-actor fashion. ${ }^{91}$ After all, domestic, transnational and global actors and strategies have pros and cons in relation to legitimacy, flexibility, bias or effectiveness in some regards; ${ }^{2}$ and cooperation between different actors is crucial to protect shared interests. ${ }^{93}$.

\footnotetext{
${ }^{88}$ See articles 25 of the American Convention on Human Rights (in conjunction with articles 1 and 2 therein), 2.3 of the International Covenant on Civil and Political Rights; or 13 of the European Convention on Human Rights, among others; and Inter-American Court of Human Rights, Advisory Opinion OC-9/87, Judicial Guarantees in states of Emergency (Arts. 27(2), 25 and 8 American Convention on Human Rights), 1987, para. 24; Human Rights Committee, General Comment No. 31, op. cit., paras. 8, 15-17, 19-20.

${ }^{89}$ See Clapham, Andrew, Human Rights Obligations of Non-State Actors, op. cit., pp. 74-75; Lauterpacht, Hersch, op. cit., pp. 27, 34.

${ }^{90}$ On non-judicial mechanisms, State-based and not, see Protect, Respect and Remedy: a Framework for Business and Human Rights, Report of the Special Representative of the Secretary-General on the issue of human rights and transnational corporations and other business enterprises, John Ruggie, A/HRC/8/5, op. cit., paras. 9, 26, 84-87, 92-103; Guiding Principles on Business and Human Rights: Implementing the United Nations "Protect, Respect and Remedy" Framework, Report of the Special Representative of the Secretary General on the issue of human rights and transnational corporations and other business enterprises, John Ruggie, A/HRC/17/31, 21 March 2011, commentary to principles 25 and 27 through 31; Alexandra Gatto, op. cit., at 428-429, 431; Reinisch, August, op. cit., pp. 53, 6768.

${ }^{91}$ Concerning the importance and certain features of multi-level and multi-actor approaches to dealing with issues that are internationally legally relevant, see: Nijman, Janneke, "Sovereignty and Personality: a Process of Inclusion", in Gerard Kreijen et al. (eds.), State, Sovereignty, and International Governance, Oxford University Press, 2002, pp. 133-134; Annan, Kofi A., op. cit., pp. iiiiv; Jackson, John H., Sovereignty, the WTO, and Changing Fundamentals of International Law, Cambridge University Press, 2006, pp. 73-76; Carozza, Paolo G., op. cit., pp. 78-79; Peters, Anne, "Humanity as the A and $\Omega$ of Sovereignty", European Journal of International Law, Vol. 20 No. 3, 2009, pp. 535-536; del Arenal, Celestino, op. cit., pp. 32-40, 62-66; Badia Martí, Anna, "Cooperación internacional en la lucha contra la delincuencia organizada transnacional", in Victoria Abellán Honrubia and Jordi Bonet Pérez (Dirs.), La incidencia de la mundialización en la formación y aplicación del Derecho Internacional Público, Los actores no estatales: ponencias y estudios, Bosch Editor, 2008, pp. 319-320, 324, 336-338, 342-343.

92 See Carrillo-Santarelli, Nicolás, "Enhanced Multi-Level Protection of Human Dignity in a Globalized Context through Humanitarian Global Legal Goods", German Law Journal, Vol. 13, No. o7, vol.08, $\mathrm{n}^{\circ}$. 01, Rio de Janeiro, 2015. pp. 420-457 440
} 
Some of the strategies that can be resorted to are: a) preventative, whereas others seek to respond to violations; some may be b) based on adjudication and others help to bridge accessibility gaps by means of conciliation and other alternative dispute resolution processes -being both options useful for alleged victims and alleged corporate abuses to ascertain if an allegation is true or not- $;{ }^{94}$ c) some initiatives may seek to address the effects of violations, and others seek to deal with and prevent some causes of corporate violations, for instance by disseminating the content of corporate responsibilities, being education an important element of the promotion and observance of international law. ${ }^{95}$

Apart from this, d) some mechanisms can have a binding outcome, and others one that is not mandatory but can contribute to shaping corporate attitudes, for instance by shaming offender companies or indicating standards to be followed in relation to corporate abuses in reports or studies ${ }^{96}$ (that NGOs or international and national bodies can issue), permitting companies to be contacted, ${ }^{97}$ or by using codes of

2012, pp. 846, 859-86o; Carrillo-Santarelli, Nicolás, "The Protection of Global Legal Goods", Anuario Mexicano de Derecho Internacional, Vol. XIII, 2013, at 422.

${ }^{93}$ See Statement issued by the President of the European Court of Human Rights concerning Requests for Interim Measures (Rule 39 of the Rules of the Court), available on: https://s3.amazonaws.com/s3.documentcloud.org/documents/362198/ecthr-statement-of-requestsfor-interim-measures.txt (last checked: 06/02/2014), where it is mentioned that "For the Court to be able effectively to perform its proper role in this area both Governments and applicants must cooperate fully with the Court."

${ }^{94}$ See Corporate Responsibility, the corporate responsibility coalition, "Protecting rights, repairing harm: How state-based non-judicial mechanisms can help fill gaps in existing frameworks for the protection of human rights of people affected by corporate activities", op. cit., pp. 1, 6-7, 11, 13-14, 1727; Cronstedt, Claes, "International Arbitration Tribunal on Business and Human Rights: Reshaping Access to Remedy", Remarks (Working Group on International Arbitration Tribunal on Business and Human Rights), London, 2014, at 4.

${ }^{95}$ In the context of international humanitarian law, see: Kalshoven, Frits and Zegveld, Liesbeth, Constraints on the Waging of War ( $3^{\text {rd }}$ edn.), International Committee of the Red Cross (ICRC), 2001, pp. 139-140.

${ }_{96}^{6}$ See Amnesty International, Injustice Incorporated: Corporate Abuses and the Human Rights to Remedy, 2006; International Commission of Jurists, Complicidad empresarial y responsabilidad legal. On examples of this in relation with other actors, see: Resolution 03/o8 and Press Release № 28/o8 of the Inter-American Commission on Human Rights; Inter-American Commission on Human Rights, Third Report on the Human Rights Situation in Colombia, op. cit., paras. 1-6, 26-59 of the Introduction of Chapter I; Inter-American Commission on Human Rights, Report on Terrorism and Human Rights, OEA/Ser.L/V/II.116, 22 October 2002, para. 48 (Section II, "Legal Framework for the Commission's Analysis").

${ }^{97}$ See Manual of Operations of the Special Procedures of the Human Rights Council of August 2008, adopted in June 2008 at the $15^{\text {th }}$ Annual Meeting of Special Procedures, published in August 2008 (available 
conduct with human rights elements with the goal of achieving internalization or changes in corporate culture.

Finally, some strategies seek to e) supervise corporate conduct and others promote new regulations or commitments (and corporations, NGOs or other actors could somehow even help in drafting standards or have an indirect influence on their emergence)..$^{98}$

\section{CONCLUSIONS}

Developments in international law and human rights have certainly contributed to the humanization of law by placing essential interests of human beings in a central place and reinforcing the protection of human beings when domestic controls are either unavailable or ineffective. Still, there is still much left to be done for that protection to truly reach every victim and person in need, and this requires, among others, acknowledging and responding to the facts that corporations can participate in human rights violations and that State-based and voluntary initiatives to address that participation are often insufficient, reason why binding strategies must be adopted. Different legal and non-legal processes of regulation, supervision, enforcement, persuasion, dissuasion, and others must be properly handled, because all of them can have an impact on the improvement of the protection of human rights.

http://www2.ohchr.org/english/bodies/chr/special/docs/Manual_August_FINAL_2008.doc, last checked: 06/02/2014), paras. 81-83.

${ }^{8}$ On the possible interaction of non-state entities with the content of international law, see International Law Association, Non-State Actors Committee, First Report of the Committee on NonState Actors: Non-State Actors in International Law: Aims, Approach and Scope of Project and Legal Issues, The Hague Conference, 2010, pp. 8-13; Henckaerts, Jean-Marie, "Customary International Humanitarian Law: a response to US comments", International Review of the Red Cross, vol. 89, no. 866, 2007, pp. 476-479; Pérez-Prat Durbán, Luis, "Actores no estatales en la creación y aplicación del Derecho Internacional", in Victoria Abellán Honrubia and Jordi Bonet Pérez (Dirs.), La incidencia de la mundialización en la formación y aplicación del Derecho Internacional Público: los actores no estatales: ponencias y estudios, Bosch (ed.), 2008; Bianchi, Andrea, "Globalization of Human Rights: The Role of Non-state Actors", in Gunther Teubner (ed.), Global Law Without a State, Dartmouth (ed.), 1997, pp. 183-202. Some examples of agreements with human rights provisions in which nonstate entities are parties are: the Memorandum of Understanding between the Justice and Equality Movement (JEM) and the United Nations regarding Protection of Children in Darfur of 21 July 2010 (see articles 1 through 4); Inter-American Commission on Human Rights, "Report on the Situation of Human Rights in El Salvador", OEA/Ser.L/.85, Doc. 28 rev., 11 February 1994, subsection 2 of the Background (section I), especially subsubsection 2.1 (entitled "The San José Agreement on Human Rights (July 26, 1990)). 
The emergence of an international protection of human rights originally responded to the idea that protection from State abuses could not rely exclusively on internal legal systems. ${ }^{99}$ Likewise, domestic and voluntary strategies of protection from corporate and other non-state abuses can be insufficient as well, ${ }^{100}$ due either to the fact that States may fail to protect victims despite their best efforts or to their non-binding character, events in which victimization and suffering will not be addressed and impunity could be encouraged. Moreover, domestic legal systems may fail to adopt or uphold norms on corporate and other non-state responsibilities in their internal law despite being required to- ${ }^{101}$ reason why an international regulations can prevent the presence of such gaps, prohibiting (or requiring the prohibition of) corporate participation in abuses everywhere and authorizing action by different actors and authorities (e.g. by NGO shaming or State or European Union regulation), signalling that corporate violations of human rights are unlawful and forbidden. In light of the suffering of victims and legal possibilities, the question is not if corporations actors must or can have human rights responsibilities that do not depend on the whim of State legislators or on their capacity to face or struggle with companies that can challenge them with their power or legalistic arguments, but rather how to provide international protection.

Direct international legal engagement with corporate conduct not undermine State duties, which remain thanks to the possibility of coexistence of obligations and responsibilities of entities with different natures, as examined in this article. The express recognition and condemnation of non-state violations actually highlight State obligations to prevent and respond to corporate abuses, perhaps even in extraterritorial terms (as when States create a risk of corporate violations with effects abroad or make efforts for abuses in which companies registered in them participate to be silenced). Additionally, existing international human rights systems will not be strained, with

\footnotetext{
${ }^{99}$ See Portmann, Roland, op. cit., pp. 254.

${ }^{100}$ See Bellal, Annyssa and Casey-Maslen, Stuart, op. cit., pp. 186-187.

${ }^{101}$ See article 2 of the American Convention on Human Rights; Inter-American Court of Human Rights, Case of Suárez-Rosero v. Ecuador, Judgment, 12 November 1997, paras. 96-99; articles 1 and 2 of the American Convention on Human Rights; Concurring Opinion of Judge A.A. Cançado Trindade to: Inter-American Court of Human Rights, Case of "The Last Temptation of Christ" (Olmedo-Bustos et al.) v. Chile, Judgment, 5 February 2001, paras. 1-5; article 4.1 of the Articles on the Responsibility of States for Internationally Wrongful Acts adopted by the International Law Commission (A/56/49(Vol.I)/Corr.4).
} 
corporate threats to human dignity being addressed in a multi-level and multi-actor framework that uses different mechanisms and strategies.

In fact, far from weakening human rights, direct international protection from corporate abuses, both in substantive (which must be developed and already exists in some cases, e.g. concerning jus cogens and international criminal law) and sometimes even in procedural terms, will help to prevent the erosion of the legitimacy of the system, whose nature as a framework of human rights could be -rightly- questioned if only some victims are protected and considered as having fundamental entitlements and victimhood, which could be understood as attaching more importance to some possible offenders than to the rights holders themselves, who must be the protagonists. Worse, failure to criticize and condemn non-state participation in violations called as such could be seen, for instance, as endorsing corporate offenders when international standards seem to (sometimes in an imbalanced way) protect them in other fields, such as investment. Furthermore, corporate responsibilities in no way legitimize or empower companies: being called a human rights violator exposes an actor to criticism, and its being a duty-holder encourages and allows others to scrutinize its actions.

The fact that sometimes non-state actions against human dignity and human rights are called as abuses ${ }^{102}$ must not lead one to think that they do not amount to violations, having been expressly called as such by authors and bodies as the InterAmerican Court of Human Rights. This idea is logically applicable to corporations; and in fact sometimes State conduct contrary to human rights is called as amounting to an abuse, but no one doubts that it is a violation. ${ }^{103}$

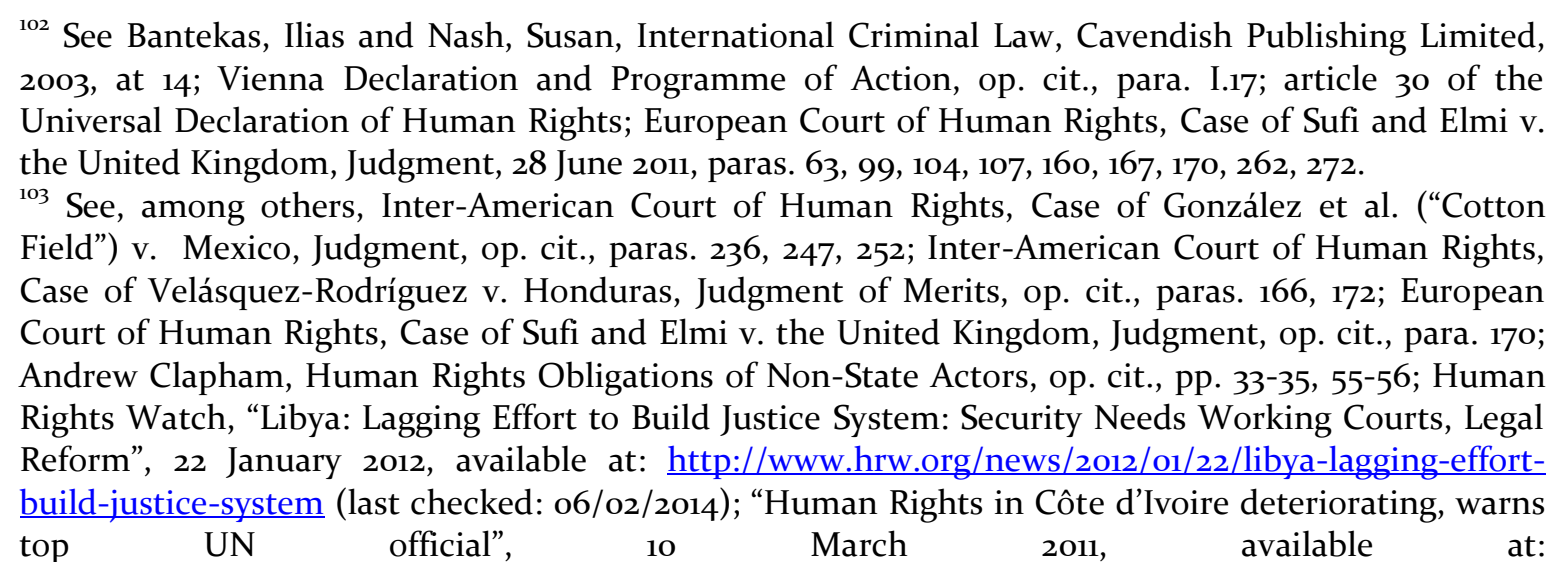
http://www.un.org/apps/news/story.asp?NewsID=37733\&Cr=ivoire\&Cr1= (last checked: o6/o2/2014); U.S. Department of State, Bureau of Democracy, Human Rights, and Labor, 2010 Country Reports on vol.08, n. 01, Rio de Janeiro, 2015. pp. 420-457 444 
It must never be forgotten that all victims have inherent worth and deserve and are entitled to protection, regardless of who violates their rights, what nature or ideologies offenders spouse, or whether the offender can generate profit or create employment: this is demanded by the human dignity that every single entity with a human nature has, and which must be recognized by law. ${ }^{104}$

Truly, a system based on human dignity calls for universal protection in terms that are comprehensive. Some alternative theoretical proposals of human rights foundations also call for protection from non-state abuses, but do so in a more limited manner and their positive contributions can be perfectly accommodated in a framework based on human dignity. ${ }^{105}$

This study defends that international law and human rights law can (and should) directly address corporate participation in violations, which is contrary to the interests and rights they enshrine and protect; ${ }^{106}$ and that to respond to this need accordingly it is possible for them to directly regulate corporate (and other non-state) duties, among other strategies. This is evinced by the fact that international law does address nonstate conduct both directly and indirectly in order to protect human dignity and human rights, as happens with norms of international criminal law, of international humanitarian law, norms that protect refugees, and even some norms of international

Human Rights Practices, Report on Colombia, 8 April 2011, available at: http://www.state.gov/documents/organization/160452.pdf (last checked: 06/o2/2014).

${ }^{104}$ This consideration, in my opinion, both founds and is required by the right to the recognition of recognition as a person "before the law", which the following sources explain: articles 6 of the Universal Declaration of Human Rights, 3 of the American Convention on Human Rights, 16 of the International Covenant on Civil and Political Rights, and XVII of the American Declaration of the Rights and Duties of Man, among others (the last cited article says that "[e]very person has the right to be recognized everywhere as a person having rights and obligations, and to enjoy the basic civil rights"); Inter-American Court of Human Rights, Case of the Girls Yean and Bosico v. Dominican Republic, Judgment, 8 September 2005, paras. 176, 179-180.

${ }^{105}$ See, for instance, the theoretical proposal found in: Goodhart, Michael, "Human Rights and NonState Actors: Theoretical Puzzles", in George Andreopoulos et al., Non-State Actors in the Human Rights Universe, Kumarian Press, Inc., 2006. Despite being quite interesting and calling for greater protection from non-state violations of human rights, the theory could fail to protect every right founded upon human dignity from all non-state violations, because some interpretations of that conception could lead to leaving victims of entities without a position of authority or of abuses of power out of the scope of human rights protection.

${ }^{106}$ On the notion of international and global legal goods, see: Carrillo-Santarelli, Nicolás, "Enhanced Multi-Level Protection of Human Dignity in a Globalized Context through Humanitarian Global Legal Goods", op. cit., pp. 832-840. 
human rights law expressly called as such, among others ${ }^{107}$ (all rights protecting human dignity are human rights and belong to human rights law); ${ }^{108}$ confirming that international law ${ }^{109}$ can directly protect human rights from non-state threats. Some of those norms even envisage direct non-state obligations and permit the supervision of non-state conduct in light of human rights standards by international bodies, as happens with the European Convention on Human Rights or the Convention on the Rights of Persons with Disabilities and its Optional Protocol. ${ }^{110}$ This confirms both that international law can directly regulate non-state obligations and that the field of human rights encompasses all norms protecting them, not just those called as such expressly.

That being said, as expressed at the beginning of the presentation of these conclusions, there is still much left to be done to truly and fully protect all victims. Hence, gaps must be filled, and it is possible to do so. International law can change, and human rights law must evolve regarding protection from corporate conduct. It is important to bear in mind that if an entity lacks certain international human rights obligations, it can have them in the future. ${ }^{\mathrm{II}}$

All victims suffer, whoever they are and whoever offenders are. Denying the existence or legal relevance of corporate abuses under human rights law and the need

\footnotetext{
${ }^{107}$ See, among other examples, Office of the United Nations High Commissioner for Refugees, Handbook on Procedures and Criteria for Determining Refugee Status under the 1951 Convention and the 1967 Protocol relating to the Status of Refugees, HCR/IP/4/Eng/REV.1, Reedited, Geneva, 1992, para. 65; article 4 of the Optional Protocol to the Convention on the Rights of the Child on the involvement of children in armed conflict; Rodehäuser, Tilman, op. cit.; Human Rights Council, Report of the independent international commission of inquiry on the Syrian Arab Republic, A/HRC/22/59, 5 February 2013, para. 44; Andrew Clapham, Human Rights Obligations of Non-State Actors, op. cit., pp. 74-75.

${ }_{108}$ See Inter-American Court of Human Rights, Advisory Opinion OC-16/99, The Right to Information on Consular Assistance in the Framework of the Guarantees of the Due Process of Law, 1 October 1999, Opinion 2, at p. 64.

${ }^{109}$ International law, in my opinion, should be more properly called jus gentium, given how it regulates intra-gentes and inter-gentes aspects, among others such as cosmopolitan, human and collective dimensions. See Gómez Robledo, Antonio, Fundadores del Derecho Internacional (Vitoria, Gentili, Suárez, Grocio), Universidad Nacional Autónoma de México, 1989, pp. 14-15, 98-99; Rafael Domingo, ¿Qué es el derecho global?, Thomson Aranzadi, 2007, at 71-72; Remiro Brotóns, Antonio et al., Derecho Internacional, McGraw-Hill, 1997, pp. XLV-XLVI.

${ }^{110}$ See articles 59.2 of the European Convention on Human Rights, 17 of Protocol 14 to the European Convention on Human Rights, 1.8).2 of the Treaty of Lisbon, 43 and 44 of the Convention on the Rights of Persons with Disabilities, 11 and 12 of the Optional Protocol to the Convention on the Rights of Persons with Disabilities, or 96.3 of Protocol I to the Geneva Conventions of 1949; and Commentaries of the ICRC to the last mentioned Protocol, paras. 3764-3769, 3774.

${ }^{11}$ See United States Court of Appeals for the Second Circuit, Kiobel v. Royal Dutch Petroleum, Docket Nos. 06-480o-cv, 06-4876-cv, Decision of 17 September 2010, at 49.
} 
to legally respond to and prevent them contradicts the bases of positive State duties and the foundations and basic features of human rights law, and also constitutes an affront to the victims of non-state violations, because it is unacceptable to consider that human rights law has nothing to say directly and without domestic legal mediation when a human being is killed by someone hired by a company, that somehow and for arcane and highly artificial theoretical reasons his right to life is supposedly not violated, or that victims of abuses in a labor context, as some children, or populations affected by irresponsible corporate behavior, allegedly have no human rights entitlements to request protection, when the opposite is true: protection from corporate abuses is required by law. Sometimes this is done in an indirect fashion that can fall short of their needs, but since international law can offer a more intense and direct protection from violations and threats attributable to non-state entities, it must do so, because victims may find no effective remedies otherwise. This is what the inspiration and idea of human rights, which are not called mere rights against States -which is but part of their mission-, and their legal embodiment, demand. Part of their inspiration is that of solidarity with all human beings and victims and condemnation of abuses against human dignity, after all. ${ }^{112}$ That being said, corporations can also be very positive actors and promote the enjoyment of human rights, ${ }^{113}$ for instance generating employment and promoting responsible behavior or human rights standards, and that must not be forgotten either.

\section{A NECESSIDADE E POSSIBILIDADE DE UMA ABORDAGEM VINCULADA DAS RESPONSABILIDADES DAS CORPORAÇÕES INTERNACIONAIS POR VIOLAÇÕES DE DIREITOS HUMANOS}

\section{Resumo}

Todas as vítimas de violações não-estatais, incluindo as corporações, têm direito a uma proteção total. No entanto, sob paradigmas estato-cêntricos e voluntários de responsabilidade social, violações causadas por corporações podem permanecer

\footnotetext{
${ }^{112}$ See Clapham, Andrew, Human Rights: a Very Short Introduction, op. cit., pp. 11, 28, 30, 131; Andrew Clapham, Human Rights Obligations of Non-State Actors, op. cit., at 107.

${ }^{113}$ See Pariotti, Elena, op. cit., at 105.
} 
impunes e as vítimas abandonadas. Isso seria contrário à fundação e aos princípios fundamentais do direito internacional dos direitos humanos, à dignidade humana, à equidade e à universalidade. À luz disto, o artigo discute porque a lei internacional permite criar obrigações diretas das corporações por violações de direitos humanos e que estratégias para promover e proteger os direitos humanos por parte de potenciais abusos das corporações podem ser utilizadas.

Palavras-chave: Entidades não estatais; obrigações internacionais; proteção da dignidade humana; análise centrada no indivíduo do direito internacional; Negócios corporativos e direitos humanos.

\section{BIBLIOGRAPHY}

ADORNO, Roberto. Human dignity and human rights as a common ground for a global bioethics, Journal of Medicine and Philosophy, 2009, at 4 (version available at: http://www.unesco.org.uy/ci/fileadmin/shs/redbioetica/dignidad_Andorno.pdf, last checked: 31/o1/2014).

ALMQVIST, Jessica. Facing the Victims in the Global Fight against Terrorism, FRIDE Working Paper 18, 2006.

ALVAREZ, José E. Are Corporations "Subjects" of International Law?, Santa Clara Journal of International Law, Vol. 9, 2011.

AMNESTY INTERNATIONAL. Injustice Incorporated: Corporate Abuses and the Human Rights to Remedy, 2006.

ANNAN, Kofi A., Foreword, United Nations Convention against Transnational Organized Crime and the Protocols Thereto, United Nations Office on Drugs and Crime, 2004, pp. iii-iv. Available on: http://www.unodc.org/documents/treaties/UNTOC/Publications/TOC\%2oConvention/ TOCebook-e.pdf

ARENAL, Celestino, La nueva sociedad mundial y las nuevas realidades internacionales: un reto para la teoría y para la política, in Cursos de Derecho Internacional y Relaciones Internacionales de Vitoria-Gasteiz 2001, Bilbao, 2002,

BADIA MARTÍ, Anna. Cooperación internacional en la lucha contra la delincuencia organizada transnacional, in Victoria Abellán Honrubia and Jordi Bonet Pérez (Dirs.), La incidencia de la mundialización en la formación y aplicación del Derecho Internacional Público, Los actores no estatales: ponencias y estudios, Bosch Editor, 2008.

BANTEKAS, Ilias and NASH, Susan. International Criminal Law, Cavendish Publishing Limited, 2003. 
BELLAL, Annyssa and CASEY-MASLEN, Stuart. Enhancing Compliance with International Law by Armed Non-State Actors, Goettingen Journal of International Law (GoJIL), Vol. 3, 2011.

BIANCHI, Andrea. Globalization of Human Rights: The Role of Non-state Actors, in Gunther Teubner (ed.), Global Law Without a State, Dartmouth (ed.), 1997.

BIRÓ, Gáspar and MOTOC, Antoanella-Iulia. Working paper on human rights and non-State actors, E/CN.4/Sub.2/2005/40, 11 July 2005.

BROTÓNS, Remiro, Antonio et al., Derecho Internacional: Curso General, Tirant Lo Blanch, 2010.

BROWNLIE, Ian. The Rule of Law in International Affairs: International Law at the Fiftieth Anniversary of the United Nations, Martinus Nijhoff Publishers, 1998.

CAPIE, David. Influencing Armed Groups: Are there Lessons to Be Drawn from Socialization Literature?, in: Geneva Call, Exploring Criteria \& Conditions for Engaging Armed Non-State Actors to Respect Humanitarian Law \& Human Rights Law, Conference Report-Geneva, 4-5 June 2007.

CAROZZA, Paolo G. Subsidiarity as a Structural Principle of International Human Rights Law, American Journal of International Law, Vol. 97, 2003.

CARRILLO-SANTARELLI, Nicolás. Enhanced Multi-Level Protection of Human Dignity in a Globalized Context through Humanitarian Global Legal Goods, German Law Journal, Vol. 13, No. 07, 2012.

CARRILLO-SANTARELLI, Nicolás. The Protection of Global Legal Goods, Anuario Mexicano de Derecho Internacional, Vol. XIII, 2013.

CASSESE, Antonio. Remarks on Scelle's Theory of "Role Splitting" (dédoublement fonctionnel) in International Law, European Journal of International Law, Vol. 1, 1990.

When May Senior State Officials Be Tried for International Crimes? Some Comments on the Congo v. Belgium Case, European Journal of International Law (EJIL), Vol. 13, 2002.

CHENG, Bin. General Principles of Law as Applied by International Courts and Tribunals, Cambridge University Press, 2006.

CLAPHAM, Andrew and JERBI, Scott. Categories of Corporate Complicity in Human Rights Abuses, Hastings International and Comparative Law Journal, Vol. 24, 2001.

CLAPHAM, Andrew. Human Rights Obligations of Non-State Actors, Oxford University Press, 2006. 
COMMITTEE ON ECONOMIC, SOCIAL AND CULTURAL RIGHTS. General Comment No. 16, The equal right of men and women to the enjoyment of all economic, social and cultural rights (art. 3 of the International Covenant on Economic, Social and Cultural Rights), E/C.12/2005/4, 11 August 2005.

CORTÉS, José Manuel. Las Organizaciones Internacionales: Codificación y Desarrollo Progresivo de su Responsabilidad Internacional, Instituto Andaluz de Administración Pública, 2008.

CRONSTEDT, Claes, International Arbitration Tribunal on Business and Human Rights: Reshaping Access to Remedy, Remarks (Working Group on International Arbitration Tribunal on Business and Human Rights), London, 2014.

DOMINGO, Rafael. ¿Qué es el derecho global?, Thomson Aranzadi, 2007.

DONNELLY, Jack. Human Rights and Human Dignity: An Analytic Critique of NonWestern Conceptions of Human Rights, The American Political Science Review, Vol. 76, 1982.

DUFRESNE, Robert. Review of: Liesbeth Zegveld, The Accountability of Armed Opposition Groups in International Law, European Journal of International Law, Vol. 15, 2004.

ESER, Albin. Individual Criminal Responsibility: Mental Elements-Mistake of Fact and Mistake of Law, Reprints from: Antonio Cassese et al. (eds.), The Rome Statute of the International Criminal Court: A Commentary, Oxford University Press, 2002.

EUROPEAN COURT OF HUMAN RIGHTS, GRAND CHAMBER. Case of Oršuš and other v. Croatia, Judgment, Joint Party Dissenting Opinion of Judges Jungwiert, Vajić, Kovler, Gyulumyan, Jaeger, Myjer, Berro-Lefèvre and Vučinić to: European Court of Human Rights, Grand Chamber, Case of Oršuš and other v. Croatia, Judgment, 16 March 2010.

Case of Al-Adsani v. The United Kingdom, Judgment, 21 November 2001.

Case of Giuliani and Gaggio v. Italy, Application no. 23458/o2, Judgment, 24 March 2001.

Case of Mastromatteo v. Italy, Judgment, 24 October 2002.

Case of N. v. Sweden, Application no. 23505/o9, Judgment, 20 July 2010.

Case of Opuz v. Turkey, Judgment, 9 June 2009.

Case of Rantsev v. Cyprus and Russia, Judgment, 7 January 2010.

Case of Sufi and Elmi v. the United Kingdom, Judgment, 28 June 2011.

Fourth Section, Case of Hajduová v. Slovakia, Judgment, 30 November 2010.

Case of Kononov v. Latvia, Judgment, 17 May 2010.

EUROPEAN UNION LAW. Sources of European Union law, available at: http://europa.eu/legislation_summaries/institutional_affairs/decisionmaking_process/l 14534_en.htm (last checked: 04/02/2014). 
FIELDING, Alex. Sainovic Appeal rejects 'specific direction', but was it necessary?, Beyond The Hague: Thoughts on international justice from The Hague and beyond, 24 January 2014, available at: http://beyondthehague.com/2014/o1/24/sainovic-appealrejects-specific-direction-but-was-it-necessary/ (last checked: 05/04/2014).

FINNIS, John. The Priority of Persons, in Jeremy Horder (ed.), Oxford Essays in Jurisprudence, Fourth Series, Oxford University Press, 2000.

GALINDO VÉLEZ, Francisco, Consideraciones sobre la determinación de la condición de refugiado, in Sandra Namihas (Ed.), Derecho Internacional de los Refugiados, Pontificia Universidad Católica del Perú - Instituto de Estudios Internacionales, Fondo Editorial, 2001.

GARCÍA VILLEGAS, Mauricio. De qué manera se puede decir que la Constitución es importante, in Álvarez Jaramillo et al., Doce ensayos sobre la nueva Constitución, Diké, 1991.

GATTO, Alexandra, Corporate Social Responsibility in the External Relations of the EU, in Yearbook of European Law, 24, 2005.

GENERAL ASSEMBLY OF THE UNITED NATIONS. Resolution 41/12o of the General Assembly of the United Nations; Helsinki Final Act of 1 August 1975 of the Conference on Security and Co-Operation in Europe; Preamble to the Vienna Declaration and Programme of Action of the World Conference on Human Rights of 1993; Preambles to the International Covenants on Economic, Social and Cultural Rights and on Civil and Political Rights.

GÓMEZ ISA, Felipe. International Protection of Human Rights, in Felipe Gómez Isa and Koen de Feyter (eds.), International Protection of Human Rights: Achievements and Challenges, University of Deusto, 2006.

GÓMEZ ROBLEDO, Antonio. El Ius Cogens Internacional: Estudio histórico-crítico, Universidad Nacional Autónoma de México, 2003.

Fundadores del Derecho Internacional (Vitoria, Gentili, Suárez, Grocio), Universidad Nacional Autónoma de México, 1989.

GOODHART, Michael. Human Rights and Non-State Actors: Theoretical Puzzles, in George Andreopoulos et al., Non-State Actors in the Human Rights Universe, Kumarian Press, Inc., 2006.

GOODMAN, Ryan and DEREK, Jinks. Incomplete Internalization and Compliance with Human Rights Law, European Journal of International Law, Vol. 19 no. 4, 2008.

HALLIDAY, Fred. The Romance of Non-state Actors, in Daphné Josselin and William Wallace (eds.), Non-state Actors in World Politics, Palgrave (ed.), 2001.

HENCKAERTS, Jean-Marie, Customary International Humanitarian Law: a response to US comments, International Review of the Red Cross, vol. 89, no. 866, 2007. 
HIGGINS, Rosalyn. Problems and Process: International Law and How We Use It, Oxford University Press, 2004.

HILLEMANS, Carolin F. UN Norms on the Responsibilities of Transnational Corporations and Other Business Enterprises with regard to Human Rights, German Law Journal, vol. 04, 2003.

HUMAN RIGHTS COMMITTEE. Concluding Observations on Kosovo (Serbia), CCPR/C/UNK/CO/1, 14 August 2006.

General Comment No. 18, Non-discrimination, 10 November 1989.

General Comment No. 29, States of Emergency (article 4), CCPR/C/21/Rev.1/Add.11, 31 August 2001.

General Comment No. 31, The Nature of the General Legal Obligation Imposed on States Parties to the Covenant, CCPR/C/21/Rev.1/Add. 13, 26 May 2004.

HUMAN RIGHTS COUNCIL. Report of the independent expert on the issue of human rights obligations related to access to safe drinking water and sanitation, Catarina de Albuquerque, A/HRC/15/31, 29 June 2010.

Report of the independent international commission of inquiry on the Syrian Arab Republic, A/HRC/19/69, 22 February 2012.

Report of the independent international commission of inquiry on the Syrian Arab Republic, A/HRC/22/59, 5 February 2013.

Resolution 15/9 adopted by the Council, Human rights and access to safe drinking water and sanitation, A/HRC/RES/15/9, 6 October 2010.

Manual of Operations of the Special Procedures of the Human Rights Council of August 2008, adopted in June 2008 at the $15^{\text {th }}$ Annual Meeting of Special Procedures, published in August 2008 (available at http://www2.ohchr.org/english/bodies/chr/special/docs/Manual_August_FINAL_20o8. doc, last checked: 06/02/2014).

HUMAN RIGHTS WATCH. Human Rights in Côte d'Ivoire deteriorating, warns top UN official, 10 March 2011, available at: http://www.un.org/apps/news/story.asp?NewsID=37733\&Cr=ivoire\&Cr1= (last checked: 06/02/2014)

Libya: Lagging Effort to Build Justice System: Security Needs Working Courts, Legal Reform, 22 January 2012, available at: http://www.hrw.org/news/2012/o1/22/libyalagging-effort-build-justice-system (last checked: 06/02/2014).

INTER-AMERICAN COMMISSION OF HUMAN RIGHTS. Hearing on the Impact of Canadian Mining Activities on Human Rights In Latin America, held on the 28th of October, 2014, available here: https://www.youtube.com/watch?v=OWYue8FP9ZY

Press Release 114/10, IACHR Deplores Acts of Violence in Prisons in Brazil.

Press Release 19/12, IACHR Deplores Deaths in Fire in Honduras Prison.

Report № 62/o2, Merits, Case 12.285, Michael Domingues v. United States, 22 October 2002.

Report on Terrorism and Human Rights, OEA/Ser.L/V/II.116, 22 October 2002. 
Advisory Opinion OC-10/89, Interpretation of the American Declaration of the Rights and Duties of Man within the Framework of article 64 of the American Convention on Human Rights, 14 July 1989.

Advisory Opinion OC-14/94, International Responsibility for the Promulgation and Enforcement of Laws in Violation of the Convention, 9 December 1994.

Advisory Opinion OC-16/99, The Right to Information on Consular Assistance in the Framework of the Guarantees of the Due Process of Law, 1 October 1999.

Advisory Opinion OC-9/87, Judicial Guarantees in states of Emergency (Arts. 27(2), 25 and 8 American Convention on Human Rights), 1987.

2003.

Case of Baena-Ricardo et al. v Panama, Competence Judgment, 28 November

Case of Castillo-Petruzzi et al. v. Peru, Judgment, 30 May 1999. 2009.

Case of González et al. ("Cotton Field") v. Mexico, Judgment, 16 November

Case of Jessica Lenahan (Gonzalez) et al. v. United States, Case 12.626, Merits Report No. 80/11, 21 July 2011.

Case of Suárez-Rosero v. Ecuador, Judgment, 12 November 1997.

Case of the "Street Children" (Villagrán-Morales et al.) v. Guatemala, Judgment, 19 November 1999.

Case of the Constitutional Court v. Peru, Judgment (competence), 24 September 1999.

Case of the Girls Yean and Bosico v. Dominican Republic, Judgment, 8 September 2005.

Case of the Pueblo Bello Massacre v. Colombia, Judgment, 31 January 2006.

Case of Velásquez-Rodríguez v. Honduras, Judgment of Merits, 29 July 1988.

Case of Ximenes-Lopez v. Brazil, Judgment of 4 July 2006.

Concurring Opinion of Judge A. A. Cançado Trindade to: Inter-American Court of Human Rights, Advisory Opinion OC-18/03.

Concurring Opinion of Judge A.A. Cançado Trindade to: Inter-American Court of Human Rights, Case of "The Last Temptation of Christ" (Olmedo-Bustos et al.) v. Chile, Judgment, 5 February 2001.

Norms on the responsibilities of transnational corporations and other business enterprises with regard to human rights, Sub-Commission on the Promotion and Protection of Human Rights, Fifty-fifth session, E/CN.4/Sub.2/2003/12/Rev.2, 26 August 2003.

INTERNATIONAL COURT OF JUSTICE. Accordance with International Law of the Unilateral Declaration of Independence in respect of Kosovo, Advisory Opinion, Advisory Opinion, 22 July 2010.

The Reality of Private Rights, Duties, and Participation in the International Legal Process, Michigan Journal of International Law, vol. 25, 2004.

Case concerning the Application of the Convention on the Prevention and Punishment of the Crime of Genocide (Bosnia and Herzegovina v. Serbia and Montenegro), Judgment, 26 February 2007.

Case concerning the Gabčíkovo-Nagymaros Project (Hungary/Slovakia), Judgment, 25 September 1997. 
Joint Dissenting Opinion of President Owada, Judges Simma, Abraham and Donoghue and Judge ad hoc Gaja to the Preliminary Objections Judgment of the International Court of Justice of 1 April 2011 in the Case concerning Application of the International Convention on the Elimination of all Forms of Racial Discrimination (Georgia v. Russian Federation).

Reparation for Injuries Suffered in the Service of the United Nations, Advisory Opinion, 11 April 1949.

Special Tribunal for Lebanon, Appeals Chamber, Case No. CH/AC/2010/o2, Decision on Appeal of Pre-Trial Judge's Order regarding Jurisdiction and Standing, 10 November 2010.

INTERNATIONAL LAW ASSOCIATION. Non-State Actors Committee, Report: Preliminary issues for the ILA Conference in Rio de Janeiro, 2008.

Non-State Actors Committee, First Report of the Committee on Non-State Actors: Non-State Actors in International Law: Aims, Approach and Scope of Project and Legal Issues, The Hague Conference, 2010.

Draft Articles on the Responsibility of States for Internationally Wrongful Acts, with commentaries, 2001.

INTERNATIONAL TRIBUNAL FOR PROSECUTION OF PERSONS RESPONSIBLE FOR SERIOUS VIOLATIONS OF INTERNATIONAL HUMANITARIAN LAW COMMITTES IN THE TERRITORY OF FORMER YOUGOSLAVIA SINCE 1991. Prosecutor v. Anto Furundzija, Judgement, 10 December 1998.

JACKSON, John H., Sovereignty, the WTO, and Changing Fundamentals of International Law, Cambridge University Press, 2006.

JOCHNICK, Chris, Confronting the Impunity of Non-State Actors: New Fields for the Promotion of Human Rights, Human Rights Quarterly, Vol. 21, 1999.

KALSHOVEN, Frits and ZEGVELD, Liesbeth. Constraints on the Waging of War $\left(3^{\text {rd }}\right.$ edn.), International Committee of the Red Cross (ICRC), 2001.

KEITNER, Chimène I. Rights Beyond Borders, The Yale Journal of International Law, vol. 36, 2011. 2008.

Conceptualizing Complicity in Alien Tort Cases, Hastings Law Journal, vol. 6o,

KELSEN, Hans, Pure Theory of Law, University of California Press, 1978.

KLABBERS, Jan. International Law, Cambridge University Press, 2013.

KNOX, John H. Horizontal Human Rights Law, American Journal of International Law, Vol. 102, No. 1, 2008.

The Human Rights Council Endorses "Guiding Principles" for Corporations, ASIL Insights, Vol. 15, Issue 21, 2011. 
KOH, Harold. Why Do Nations Obey International Law? The Yale Law Journal, vol. 106, 1997 .

MANACORDA, Stefano and MELONI, Chantal. Indirect Perpetration versus Joint Criminal Enterprise: Concurring Approaches in the Practice of International Criminal Law? Journal of International Criminal Justice, 2011.

McDOUGAL, Myres S. Some basic theoretical concepts about international law: a policy-oriented framework of inquiry, The Journal of Conflict Resolution, Vol. IV, 1960.

McDOUGAL, Myres S. and LASSWELL, Harold D. The Identification and Appraisal of Diverse Systems of Public Order, The American Journal of International Law, Vol. 53, 1959 .

MEIJKNECHT, Anna. Towards International Personality: The Position of Minorities and Indigenous Peoples in International Law, Intersentia, 2001.

MERON, Theodor, The Humanization of International Law, Martinus Nijhoff, 2006 The Humanization of International Law, American Journal of International Law, Vol. 94, No. 2, 2000.

MILANOVIC, Marko, The Self-Fragmentation of the ICTY Appeals Chamber, EJIL: Talk!, 23 January 2014, available at: http://www.ejiltalk.org/the-self-fragmentation-ofthe-icty-appeals-chamber $\angle$ (last checked: 05/04/2014).

The ICJ and Evolutionary Treaty Interpretation, EJIL: Talk!, 14 July 2009, available at: http://www.ejiltalk.org/the-icj-and-evolutionary-treaty-interpretation/ (last checked: 04/02/2014).

NIJMAN, Janne E., Non-state actors and the international rule of law: Revisiting the 'realist theory' of international legal personality, Amsterdam Center for International Law Research Paper Series, Non-State Actors in International Law, Politics and Governance Series, 2010.

Sovereignty and Personality: a Process of Inclusion, in Gerard Kreijen et al. (eds.), State, Sovereignty, and International Governance, Oxford University Press, 2002.

O'DONELL, Daniel. Derecho Internacional de los Derechos Humanos, Oficina en Colombia del Alto Comisionado de las Naciones Unidas para los Derechos Humanos, 2004 .

OFFICE OF THE UNITED NATIONS HIGH COMISSIONER FOR REFUGEES. Handbook on Procedures and Criteria for Determining Refugee Status under the 1951 Convention and the 1967 Protocol relating to the Status of Refugees, HCR/IP/4/Eng/REV.1, Reedited, Geneva, 1992. 
PARIOTTI, Elena. Non-State Actors, International Law, and Human Rights, in Sanford R. Silverburg (ed.), International Law: Contemporary Issues and Future Developments, Westview Press, 2011.

PAUST, Jordan J. Nonstate Actor Participation in International Law and the Pretense of Exclusion, Virginia Journal of International Law, Vol. 51, Number 4, 2011, pp. 985-1000.

The Other Side of Right: Private Duties Under Human Rights Law, Harvard Human Rights Journal, Vol. 5, 1992.

PENTASSUGLIA, Gaetano. Review of: Meijknecht, Anna. Towards International Personality: The Position of Minorities and Indigenous Peoples in International Law, European Journal of International Law, Vol. 14, 2003.

PÉREZ-PRAT DURBAN, Luis. Actores no estatales en la creación y aplicación del Derecho Internacional, in Victoria Abellán Honrubia and Jordi Bonet Pérez (Dirs.), La incidencia de la mundialización en la formación y aplicación del Derecho Internacional Público: los actores no estatales: ponencias y estudios, Bosch (ed.), 2008.

PETERS, Anne. Humanity as the $A$ and $\boldsymbol{\Omega}$ of Sovereignty, European Journal of International Law, Vol. 20 No. 3, 2009.

PORTMANN, Roland. Legal Personality in International Law, Cambridge University Press, 2010.

REINISCH, August, The Changing International Legal Framework for Dealing with Non-State Actors, in Philip Alston (ed.), Non-State Actors and Human Rights, Oxford University Press, 2005.

ROBISON, Darryl. The Mysterious Mysteriousness of Complementarity, Criminal Law Forum, Vol. 21, No. 1, 2010.

RODEHÄUSER, Tilman. Progressive Development of International Human Rights Law: The Reports of the Independent International Commission of Inquiry on the Syrian Arab Republic, EJIL: Talk!, 13 April 2013.

\section{SAAVEDRA ALESSANDRI, Pablo. Las Reparaciones en el Sistema Interamericano} de Derechos Humanos, pp. 4, 14-16, available at: http://www.usergioarboleda.edu.co/instituto_derechos_humanos/material/cv/reparaci ones.pdf (last checked: 05/04/2014).

SCHACHTER, Oscar. Human Dignity as a Normative Concept, American Journal of International Law, Vol. 77, 1983.

SEN, Amartya. Elements of a Theory of Human Rights, Philosophy \& Public Affairs, Vol. 32, 2004. 
SENSEN, Oliver. Human Dignity in Historical Perspective: The Contemporary and Traditional Paradigms, European Journal of Political Theory, Vol. 10, 2011.

U.S. DEPARTAMENT OF STATE, BUREAU OF DEMOCRACY, HUMAN RIGHTS, AND LABOR. ; U.S. Country Reports on Human Rights Practices, Report on Colombia, 8 April 2011, available at: http://www.state.gov/documents/organization/160452.pdf (last checked: 06/02/2014).

UNITED NATIONS. Guiding Principles on Business and Human Rights: Implementing the United Nations "Protect, Respect and Remedy" Framework, Report of the Special Representative of the Secretary General on the issue of human rights and transnational corporations and other business enterprises, John Ruggie, A/HRC/17/31, 21 March 2011.

UNITED STATES COURT OF APPEALS FOR THE SECOND CIRCUIT. Kiobel v. Royal Dutch Petroleum, Docket Nos. 06-48oo-cv, o6-4876-cv, Decision of 17 September 2010.

UNITED STATES COURT OF APPEALS FOR THE SEVENTH CIRCUIT. Boimah Flomo et al. v. Firestone Natural Rubber Co., LLC, Decision of 11 July 2011.

VAN BOVEN, Theo. The United Nations Basic Principles and Guidelines on the Right to a Remedy and Reparation for Victims of Gross Violations of International Human Rights Law and Serious Violations of International Humanitarian Law, United Nations Audiovisual Library of International Law.

VILLALPANDO, Santiago. The Legal Dimension of the International Community: How Community Interests are Protected in International Law, European Journal of International Law, Vol. 21, 2010.

VILLÁN DURÁN, Carlos. Curso de Derecho Internacional de los Derechos Humanos, Editorial Trotta, 2006.

WIRTZ, Raoul. Moral responsibility in organizations, in: Ronald Jeurissen (ed.), Ethics \& Business, Royal Van Gorcum, 2007.

Trabalho enviado em 16 de fevereiro de 2015.

Aceito em 18 de fevereiro de 2015. 